\title{
Signaling in Cell Differentiation and Morphogenesis
}

\author{
M. Albert Basson \\ Department of Craniofacial Development, King's College London, London SE1 9RT, United Kingdom \\ Correspondence: albert.basson@kcl.ac.uk
}

\section{SUMMARY}

All the information to make a complete, fully functional living organism is encoded within the genome of the fertilized oocyte. How is this genetic code translated into the vast array of cellular behaviors that unfold during the course of embryonic development, as the zygote slowly morphs into a new organism? Studies over the last 30 years or so have shown that many of these cellular processes are driven by secreted or membrane-bound signaling molecules. Elucidating how the genetic code is translated into instructions or signals during embryogenesis, how signals are generated at the correct time and place and at the appropriate level, and finally, how these instructions are interpreted and put into action, are some of the central questions of developmental biology. Our understanding of the causes of congenital malformations and disease has improved substantially with the rapid advances in our knowledge of signaling pathways and their regulation during development. In this article, I review some of the signaling pathways that play essential roles during embryonic development. These examples show some of the mechanisms used by cells to receive and interpret developmental signals. I also discuss how signaling pathways downstream from these signals are regulated and how they induce specific cellular responses that ultimately affect cell fate and morphogenesis.

\section{Outline}

1 Introduction

2 Overview of key signaling pathways in development

3 The establishment of signaling centers in the embryo

4 The orchestration of cell differentiation and morphogenesis
5 Signal strength and duration: interpretation and regulation

6 Integrating multiple signaling pathways during development

7 Mechanical biology and morphogenesis

8 Concluding remarks

References

Editors: Patrick P.L. Tam, W. James Nelson, and Janet Rossant

Additional Perspectives on Mammalian Development available at www.cshperspectives.org

Copyright (C 2012 Cold Spring Harbor Laboratory Press; all rights reserved; doi: 10.1101/cshperspect.a008151

Cite this article as Cold Spring Harb Perspect Biol 2012;4:a008151 


\section{INTRODUCTION}

Cells in the developing embryo are in constant communication with their neighbors, and the molecules they use to send and receive signals are essential for normal embryogenesis. Several intracellular signaling pathways have been identified, some of which are activated in response to secreted growth factors. In cases where the secreted factors form a concentration gradient and cell fate is specified as a function of growth factor concentration, these molecules are referred to as morphogens. Examples include the sonic hedgehog $(\mathrm{SHH})$, wingless (WNT), retinoic acid (RA), bone morphogenetic protein (BMP), and fibroblast growth factor (FGF) pathways. In addition to determining cell fate, these pathways also control proliferation and survival. Planar cell polarity (PCP) pathways, on the other hand, are used by cells to interpret their orientation within the plane of a tissue and control cell shape and polarity. The Notch signaling pathway is used by adjacent cells to communicate and control binary cell fate decisions and the formation of precise tissue patterns and boundaries. In this article, I will first provide a detailed overview of a few selected pathways. Then, I will refer to specific examples to show how a single signaling pathway may be used repeatedly for several purposes during embryogenesis, how small differences in signal strength is interpreted by cells, how signaling pathways are regulated and integrated with each other and finally, how morphogenesis and cell fate may be controlled.

\section{OVERVIEW OF KEY SIGNALING PATHWAYS IN DEVELOPMENT}

\subsection{Receptor Tyrosine Kinase Signaling}

Receptor tyrosine kinases (RTKs) are receptors that phosphorylate tyrosine residues. So far, 58 RTKs, divided into 20 different families have been identified (Lemmon and Schlessinger 2010). Each RTK can be activated by several secreted ligands depending on the context. RTK signaling represents a versatile signaling module with many diverse functions during development. Accordingly, numerous developmental syndromes and diseases are associated with mutations in RTK signaling pathways (Robertson et al. 2000). A subset of RTKs is of particular interest to developmental biologists owing to the striking developmental defects caused by their loss. These include RTKs activated by FGF, epidermal growth factor (EGF), vascular endothelial growth factor (VEGF), platelet-derived growth factor (PDGF), and glial cell line-derived growth factor (GDNF). There are too many RTK ligands to list them all and discuss their function here, however, a few examples of ligands that can activate RTKs of particular importance during embryogenesis are provided in Table 1.

\subsubsection{Intracellular RTK Signaling Cascades}

RTKs typically consist of extracellular ligand-binding and intracellular tyrosine kinase domains. Receptors are activated by binding to their cognate ligands on the cell surface. The molecular mechanisms by which different ligands activate their receptors differ but the end result is always the stabilization of a receptor dimer or oligomer with activated tyrosine kinase activity. The activation of some receptors is modulated by accessory molecules. For example, heparan sulphate proteoglycans (HSPGs) stabilize FGF:FGFR complexes by simultaneously binding to and interacting with ligand and receptor (Plotnikov et al. 1999; Schlessinger et al. 2000; Stauber et al. 2000). Activated receptor complexes are phosphorylated on one or more tyrosine residues by transphosphorylation, which increases their catalytic activity (Favelyukis et al. 2001; Furdui et al. 2006). Phosphotyrosine residues provide binding sites for downstream signaling molecules through Src homolgy-2 (SH2) or phosphotyrosine binding (PTB) domains. Among the first to be recruited are the docking proteins: FRS2, IRS1 (insulin receptor substrate-1), or Gab1 (Grb2-associated binder). These proteins contain multiple functional domains such as $\mathrm{SH} 2$ and $\mathrm{SH} 3$ that function as interaction modules. Therefore, once recruited, they interact with other signaling molecules to form multimolecular signaling complexes (Fig. 1).

Multimolecular complexes activate a number of downstream signaling pathways, including the ras/MAPK, PLC $\gamma$, and PI3K pathways (Fig. 1). Traditionally, the ras/ MAPK pathway has been associated with increased cell proliferation, the PI3K pathway with cell survival, and rho/rac activity with changes in cell shape and migration. To what extent different growth factors differentially engage downstream cascades and the mechanisms whereby such specificity is achieved are poorly understood. One mechanism identified in Xenopus involves negative feedback, which preferentially targets distinct pathways. In this case, feedback antagonists of the spred family preferentially inhibit MAPK signaling and mesoderm induction, whereas sprouty proteins inhibit PLC $\gamma$-dependent pathways and morphogenesis (Sivak et al. 2005). In addition, the downstream pathway activated and the resulting cellular response may depend on the subcellular localization of the initial signaling complex, e.g., the cytoplasmic membrane versus intracellular membranes such as endosomes (Daniels et al. 2006; Fehrenbacher and Philips 2009). However, it is becoming clear that significant crosstalk exists between different RTK signaling pathways to form intricate signaling networks. For example, activated PKC, downstream from the PLC $\gamma$ pathway, can activate Rafl, thereby augmenting extracellular signal-regulated kinase (ERK) signaling (Fig. 1) (Takahashi et al. 1999). 
Table 1. Examples of ligands that activate RTKs

\begin{tabular}{|c|c|c|c|}
\hline RTK & Ligands & Cofactors & References \\
\hline $\begin{array}{l}\text { Fibroblast growth } \\
\text { factor receptor } \\
\text { (FGFR1-4) }\end{array}$ & $\begin{array}{l}\text { FGF1-10, FGF15-FGF20, FGF22 } \\
\quad \text { (canonical FGFs) } \\
\text { FGF15/19 } \\
\text { FGF23 } \\
\text { FGF21 (hormone-like/endocrine FGFs) }\end{array}$ & $\begin{array}{l}\text { Heparan sulphate } \\
\text { proteoglycan } \\
\beta \text {-Klotho } \\
\alpha \text {-Klotho } \\
\text { Unknown }\end{array}$ & $\begin{array}{l}\text { Mohammadi et al. } 2005 \\
\text { Kurosu et al. } 2007 \\
\text { Kurosu et al. } 2006 \\
\text { Itoh } 2010\end{array}$ \\
\hline RET & GDNF, neurturin, persephin, artemin & $\begin{array}{l}\mathrm{GFR} \alpha 1, \mathrm{GFR} \alpha 2 \\
\text { GFR } \alpha 3, \mathrm{GFR} \alpha 4\end{array}$ & Airaksinen et al. 2006; Parkash et al. 2008 \\
\hline $\begin{array}{l}\text { EGFR (ErbB1) } \\
\text { ErbB2 } \\
\text { ErbB3 } \\
\text { ErbB4 }\end{array}$ & $\begin{array}{l}\text { EGF, TGF } \alpha \text {, HB-EGF, amphiregulin, } \\
\quad \text { betacellulin, epiregulin, epigen } \\
\text { Heregulin } \\
\text { Neuregulin }\end{array}$ & & $\begin{array}{l}\text { Singh and Harris } 2005 \\
\text { Significant heterodimerization of receptors } \\
\text { and cross-regulation between ligands } \\
\text { possible. }\end{array}$ \\
\hline $\begin{array}{l}\text { IGF1R, InsR } \\
\text { InsRR }\end{array}$ & $\begin{array}{l}\text { Insulin, IGF1, IGF2 } \\
\text { Unknown }\end{array}$ & & $\begin{array}{l}\text { LeRoith and Yakar 2007; Randhawa } 2008 \\
\text { Deyev et al. } 2011\end{array}$ \\
\hline PDGFR & PDGF-A, B, C, D & & Andrae et al. 2008 \\
\hline VEGFR1-3 & $\begin{array}{l}\text { VEGF-A (several isoforms produced by } \\
\text { alternative exon splicing: VEGF121, 165, 189, } \\
\text { and 206), } \\
\text { VEGF-B, VEGF-C, VEGF-D, and placental } \\
\text { growth factor (PGF) }\end{array}$ & & Kowanetz and Ferrara 2006 \\
\hline
\end{tabular}

\footnotetext{
Abbreviations: RTK, receptor tyrosine kinase; FGFR, fibroblast growth factor receptor; RET, rearranged during transfection; GDNF, glial cell line-derived growth factor; GFR, growth factor receptor; EGFR, epidermal growth factor receptor; TGF, transforming growth factor; HB, heparin-binding; IGF, insulin-like growth factor; PDGFR, platelet-derived growth factor receptor; VEGFR, vascular endothelial growth factor receptor; PGF, placental growth factor.
}

Much of our knowledge about the molecular mechanisms of RTK signal transduction comes from in vitro studies. Gene knockout experiments in mice have validated many of these findings in vivo. For example, FRS2 $\alpha$-deficient embryos fail to develop later than E7.5 owing to defects in FGF-dependent processes like gastrulation (Hadari et al. 2001; Lin et al. 2007). In vivo studies also revealed the significant functional divergence in mammalian RTK signaling components. For example, Erk1 ${ }^{-/-}$mice are fertile with only relatively subtle abnormalities (Pagès et al. 1999), whereas $E r k 2^{-/-}$embryos have defects in the formation of extraembryonic tissues and embryos die shortly after implantation (Saba-El-Leil et al. 2003).

\subsubsection{WNT Signaling}

WNT ligands are lipid-modified, secreted morphogens with diverse roles in embryonic development (Kiecker and Niehrs 2001; Dressler 2006; Marikawa 2006; Schmitt et al. 2006; Cohen et al. 2008).

WNTs signal through seven-pass transmembrane receptors called Frizzled (Fz) (Bhanot et al. 1996). The human and mouse genomes contain $19 \mathrm{WNT}$ and $10 \mathrm{Fz}$ genes. Depending on the context, canonical WNT ligands such as WNT1, WNT3a, and WNT8 can induce a secondary axis in Xenopus embryos, whereas noncanonical WNTs, like WNT4, WNT5a, and WNT11 promote convergent extension (Clevers 2006). Three major WNT signaling pathways have been identified: canonical WNT/ $\beta$-catenin, noncanonical WNT $/ \mathrm{Ca}^{2+}$, and WNT/PCP pathways (van Amerongen and Nusse 2009).

\subsubsection{Canonical WNT Signaling}

The key event in canonical signaling involves the stabilization of the downstream effector molecule, $\beta$-catenin; hence, it is also referred to as the $\mathrm{WNT} / \beta$-catenin pathway. In the absence of WNT signaling, $\beta$-catenin is degraded through the action of a destruction complex that contains Axin, adenomatous polyposis coli (APC), and glycogen synthase kinase 3 (GSK-3). GSK-3 phosphorylates $\beta$-catenin at a number of ser/thr residues to form new recognition sites for the F-box/WD repeat protein $\beta$ - TrCP. $\beta$ - TrCP is a subunit of a E3 ubiquitin ligase complex that targets $\beta$-catenin for degradation (Fig. 2) (Aberle et al. 1997).

Canonical WNT signaling requires members of the low-density lipoprotein (LRP) family, LRP5 and LRP6. Phosphorylated LRP5/6 forms a new binding site for Axin, such that Axin is recruited away from the destruction complex (Davidson et al. 2005; Zeng et al. 2005). In 
M.A. Basson

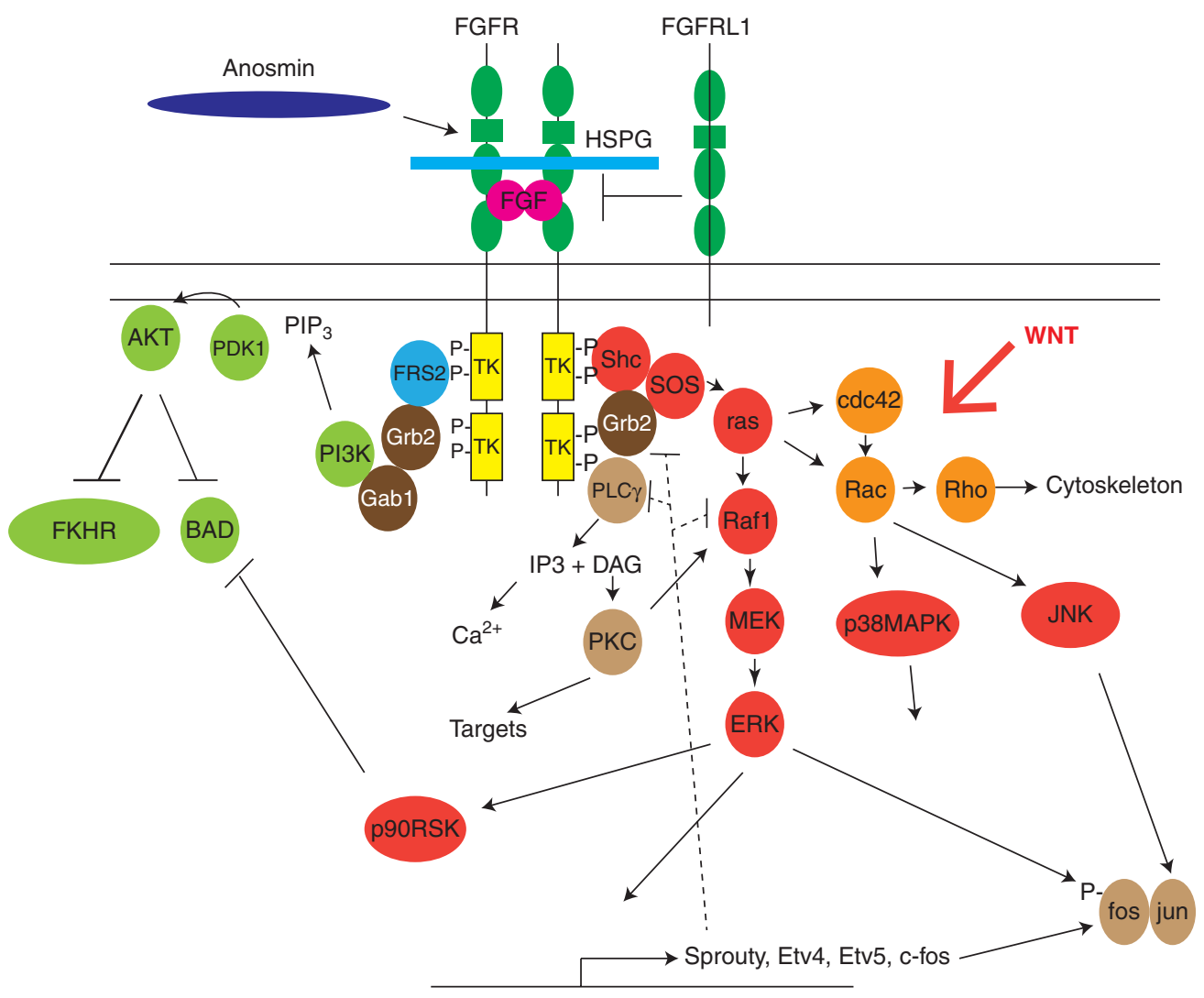

Figure 1. FGF signaling cascades, an example of RTK signaling. The formation of multimeric complexes of FGF ligand, FGF receptors (FGFR), and heparin sulphate proteoglycan (HSPG) results in the transphosphorylation of FGFRs through the action of tyrosine kinase (TK) domains. TK-deficient FGFRL1 molecules may inhibit receptor activation through competition. Several cofactors that can enhance FGFR activation such as anosmin have been identified. Phosphorylated FGFRs recruit adapter molecules such as FRS2 and Shc, which recruits Grb2 and SOS for initiation of the ras/MAPK and Gab1 for the initiation of the PI3K pathways, respectively. The guanine exchange factor SOS activates ras, which allows the signal to be transmitted to Raf1, MEK, and ERK, which translocates to the nucleus where it acts on transcriptional cofactors to alter gene expression. Sprouty genes encode feedback inhibitors of the pathway (broken lines). A key readout of signal strength is c-fos, which is regulated by ERK at both transcriptional and posttranslational levels. Activation of the PI3K pathway is associated with the recruitment and activation of AKT through $\mathrm{PIP}_{3}$ production and action of PDK1. AKT inhibits cell death pathways mediated by forkhead transcription factors (FKHR) and BAD. ERK can also inhibit cell death through the action of p90RSK on BAD. PLC $\gamma$ is activated on recruitment to activated RTKs, resulting in the release of second messengers $\mathrm{IP}_{3}$ and DAG. $\mathrm{IP}_{3}$ induces the release of intracellular $\mathrm{Ca}^{2+}$ and DAG activated-PKC, which can alter gene expression downstream and also feed into the ras/MAPK pathway by activating Raf1. Activated ras can activate other small GTPases such as rho, rac, and cdc42, which activate the p38MAPK or JNK pathways and alter the stability of the cytoskeleton. Noncanonical WNT signaling also feeds into this pathway at the level of rac and rho activation (red arrow) to affect the cytoskeleton and activate JNK.

addition, Dishevelled (Dsh) has been reported to inhibit the destruction complex by phosphorylation and inactivation of GSK3 $\beta$ by Frat/GBP; however, mice deficient for Frat appear normal, suggesting that Frat alone is not essential for normal WNT signaling (van Amerongen et al. 2005). Inhibition of the destruction complex allows the accumulation of stable, nonphosphorylated $\beta$-catenin that translocates to the nucleus and interacts with T-cell factor/lymphoid enhancer factor (TCF/LEF) complexes to alter gene expression (Clevers 2006; Gordon and Nusse 2006).

\subsubsection{Noncanonical WNT Signaling}

A noncanonical $\mathrm{Fz} / \mathrm{Ca}^{2+}$ pathway has been identified in Drosophila and lower vertebrates (Fig. 2). Fz-mediated 


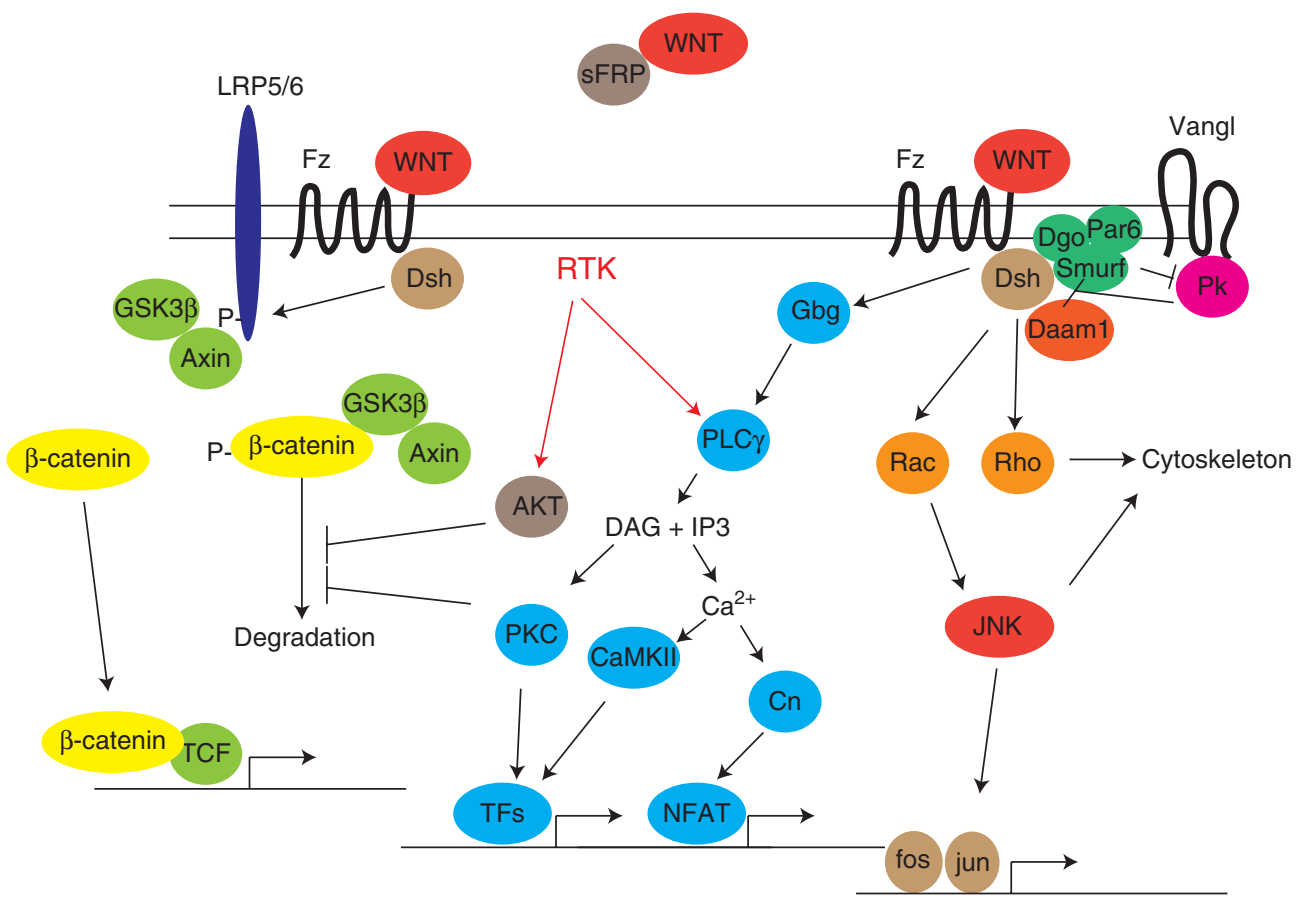

Figure 2. Canonical (left) and noncanonical (right) WNT signaling pathways. In the absence of WNT signaling, the effector of canonical WNT signaling, $\beta$-catenin is found complexed in the cytoplasm with a destruction complex containing Axin and GSK3 $\beta$. GSK3 $\beta$ phosphorylates $\beta$-catenin, which results in its targeting to and degradation by the proteasome. The binding of canonical WNT ligands to Frizzled (Fz) and LRP5/6 receptors results in the phosphorylation of LRP5/6 through the action of Dishevelled (Dsh). Phosphorylated LRP5/ 6 recruits Axin away from the destruction complex, liberating $\beta$-catenin that accumulates in the cytoplasm and translocates to the nucleus, where it interacts with transcriptional regulators of the TCF/LEF family to alter gene expression. AKT and PKC downstream from RTK signaling may inhibit the activity of the $\beta$-catenin destruction complex to promote $\beta$-catenin signaling. Noncanonical $\mathrm{WNT} / \mathrm{Ca}^{2+}$ signaling is initiated by the activation of PLC, probably through trimeric G-proteins such as Gbg. The release of $\mathrm{Ca}^{2+}$ results in the activation of NFAT (nuclear factor associated with $\mathrm{T}$ cells) transcription factors through calcineurin $(\mathrm{Cn})$. Other downstream transcription factors (TFs) are activated by PKC and CaMKII. AWnt/planar cell polarity pathway involves Diego (Dgo), Smurf, and Par6, which through cross-inhibitory interactions with Van Gogh-like (Vangl)-Prickle (Pk) complexes regulate planar cell polarity.

heterotrimeric G-protein activation causes the release of $\mathrm{Ca}^{2+}$ from intracellular stores and the activation of NFAT (nuclear factor associated with T cells) (Kühl et al. 2000; Kohn and Moon 2005). Recent evidence indicates that this pathway is also important during organogenesis in the mouse (Burn et al. 2011).

Fz receptors can also be activated and function independently of WNT ligands in a third pathway that controls PCP, referred to as the Fz/PCP pathway in Drosophila. Although the role of the Fz/PCP pathway is relatively well understood in Drosophila, the same cannot be said for this pathway in mammals. In vertebrates, WNT5A, WNT5B, and WNT11 ligands can induce PCP signals on Fz ligation (Qian et al. 2007; Gros et al. 2008; Bradley and Drissi 2011). Components of this pathway include Van Gogh-like (Vangl), Prickle, and Celsr (Flamingo) and their activation influences cell polarity through RhoA, JNK (Dsh-dependent), and Nemo-like kinase (Dsh-independent) activities. Dsh associates with a ubiquitin ligase, Smurf, which is required for PCP in mammals by targeting Prickle for degradation, possibly contributing to the asymmetric localization of Vangl/Pk complexes in the cell. Mouse embryos that lack both Smurf1 and Smurf2 have defects in PCP signaling (Narimatsu et al. 2009).

Intriguingly, WNT ligands have also been shown to bind and activate the atypical RTKs, Ryk and Ror2. These receptors may act as $\mathrm{Fz}$ coreceptors ( $\mathrm{Lu}$ et al. 2004) or activate other downstream signaling molecules like SRC kinase (Ryk) and JNK (Ror2) (Oishi et al. 2003; Zhong et al. 2011). Recently, Ror2 was shown to form a complex with Vangl2 in a WNT-dependent fashion to sense WNT ligand concentration and control PCP in chondrocytes in the developing limb (Gao et al. 2011; Wang et al. 2011). 
M.A. Basson

In summary, at least five related pathways have been identified, namely, the WNT/ $\beta$-catenin, WNT/PCP, WNT/ $\mathrm{Ca}^{+}{ }^{+}, \mathrm{WNT} / \mathrm{Ryk} / \mathrm{Src}$, and WNT/Ror2/JNK. It is likely that there is extensive overlap and cross-regulation between these different pathways (Kestler and Kühl 2008).

\subsubsection{SHH Signaling}

Three related hedgehog ligands have been identified in mice and humans: sonic hedgehog ( $\mathrm{SHH})$, Indian hedgehog (IHH), and desert hedgehog (DHH) (Ingham 2001). For the purpose of this article, I will focus exclusively on the $\mathrm{SHH}$ pathway. $\mathrm{SHH}$ is essential for the normal development of multiple organs and structures in the embryo and $S h h^{-1-}$ embryos show characteristic defects such as holoprosencephaly (Hayhurst and McConnell 2003) and loss of distal limb structures and ventral cell types in the neural tube (Chiang et al. 1996). SHH functions as a classical morphogen during development and the outcome of $\mathrm{SHH}$ signaling is a function of both $\mathrm{SHH}$ concentration and the duration of signaling (Fig. 3) (Ribes and Briscoe 2009).

Key steps in the SHH pathway, which involves ligand modification, secretion, and binding to its receptor Patched on the cell surface to relieve repression of the seven-pass transmembrane molecule Smoothened, are summarized in Figure 3 (Murone et al. 1999). The translocation of Smo into the primary cilium culminates in the nuclear accumulation of full-length Gli activator proteins (Taylor et al. 2002; Louvi and Grove 2011). Three different Gli proteins function downstream from $\mathrm{SHH}$ signaling during mammalian development, and the exact roles and interplay

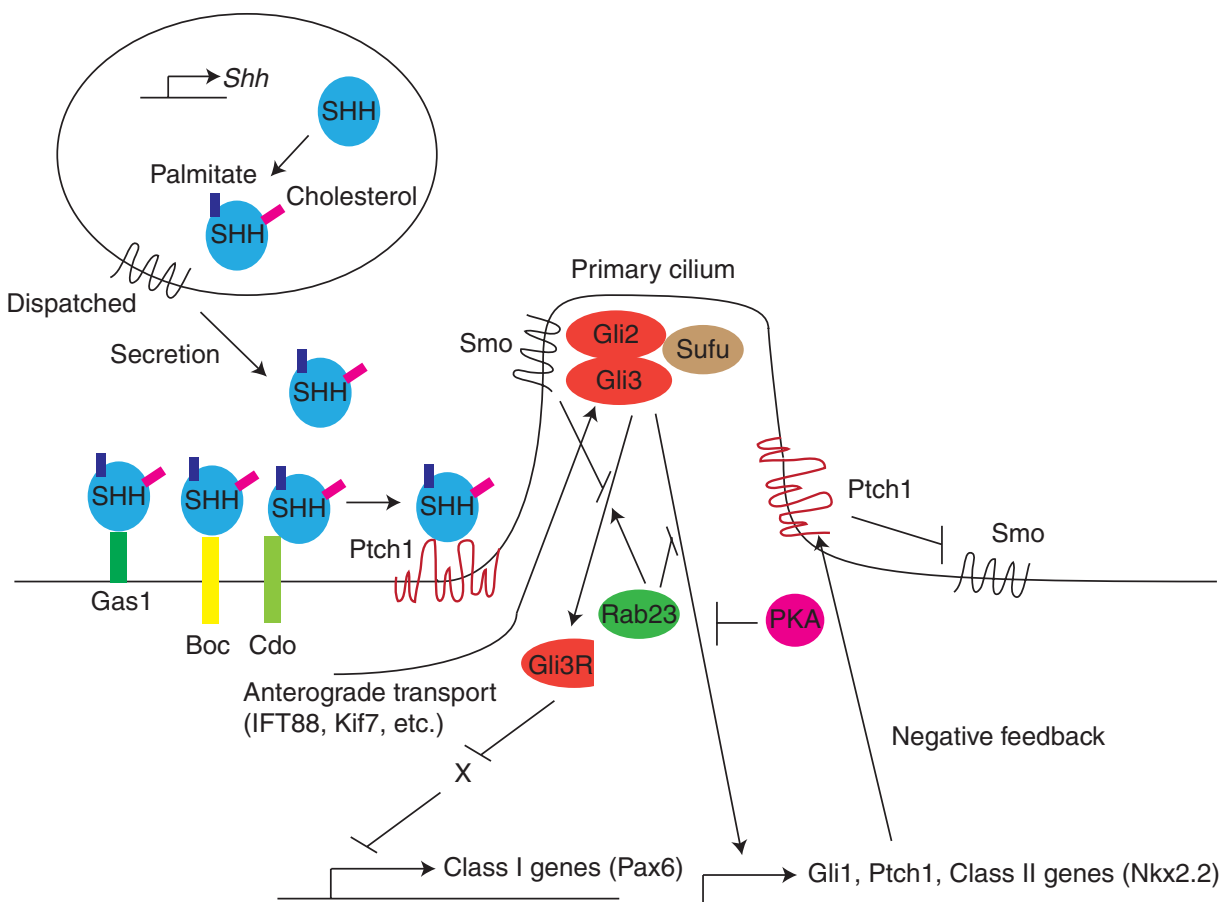

Figure 3. Sonic hedgehog $(\mathrm{SHH})$ signaling pathway. A key first step in the SHH pathway is the posttranslational processing of $\mathrm{SHH}$ protein to produce the mature SHH-N ligand, which is lipid (palmitate and cholesterol) modified (Porter et al. 1996a, 1996b). Secretion of SHH is dependent on a transmembrane protein Dispatched (Ma et al. 2002). In the absence of SHH ligand (right-hand side of figure), the 12-span transmembrane protein Patched (Ptch1) prevents a seven-pass transmembrane protein Smoothened (Smo) from entering the primary cilium. Gli3 is proteolytically cleaved with its amino-terminal fragment functioning as a transcriptional repressor of putative repressors $(\mathrm{X})$ to induce the expression of downstream targets (referred to as class I genes in neural development). When SHH binds to Ptch1, the repression of Smo is relieved and Smo moves into the cilium, where it promotes the accumulation of Gli proteins and inhibit the proteolytic cleavage of Gli3. Gli proteins translocate to the nucleus where they activate the transcription of class II genes, Gli1 and Ptch1 (Ruiz i Altaba et al. 2003; Jacob and Lum 2007). The latter produces a negative feedback loop to switch off SHH signaling. Several other regulators of SHH signaling have been identified. The intracellular protein Sufu interacts with Gli3 in a SHH-dependent manner to regulate the efficiency of Gli3 processing. Membrane proteins Gas1, Boc, and Cdo bind to SHH and may regulate the accessibility to SHH ligand to Ptch1. Rab23 promotes the expression of class I while inhibiting the expression of class II genes, and PKA can inhibit the activity of Gli2/3 activator complexes. 
between these different factors remain controversial. In the best-understood system, the neural tube, the expression of the Gli1 gene is dependent on SHH signals and is expressed at high levels where SHH signaling is active (Ruiz i Altaba et al. 2003). Gli1 and Gli2 primarily function as transcriptional activators during development. Gli3 activity is regulated at the posttranslational level: A relatively high proportion of the cleaved, repressor form of Gli3 is present in regions with little SHH signaling, whereas the processing of full-length Gli3 protein, which tends to function as a transcriptional activator, into a cleaved repressor form, is inhibited by SHH signals (Ruiz i Altaba et al. 2003; Jacob and Lum 2007). An important question to address in the future is how different levels of Gli activity are translated to cell fate changes.

\subsubsection{BMP Signaling}

The 20 or so BMPs identified thus far are members of the transforming growth factor- $\beta$ (TGF $\beta$ ) family of signaling molecules. BMPs are classified into several subfamilies: the BMP-2/4, BMP-5/6/7/8, growth and differentiation factor (GDF)-5/6/7, and BMP-9/10 groups. The disruption of BMP signaling in the mouse results in multiple defects. In these contexts, BMP is an important regulator of cell proliferation and differentiation (Kishigami and Mishina 2005; Lowery and de Caestecker 2010). BMP ligands clearly also function as morphogens during mammalian development (Behesti et al. 2006).

TGF $\beta$ ligands activate ser-thr kinase receptors of which there are two classes: type I and type II receptors (Fig. 4).

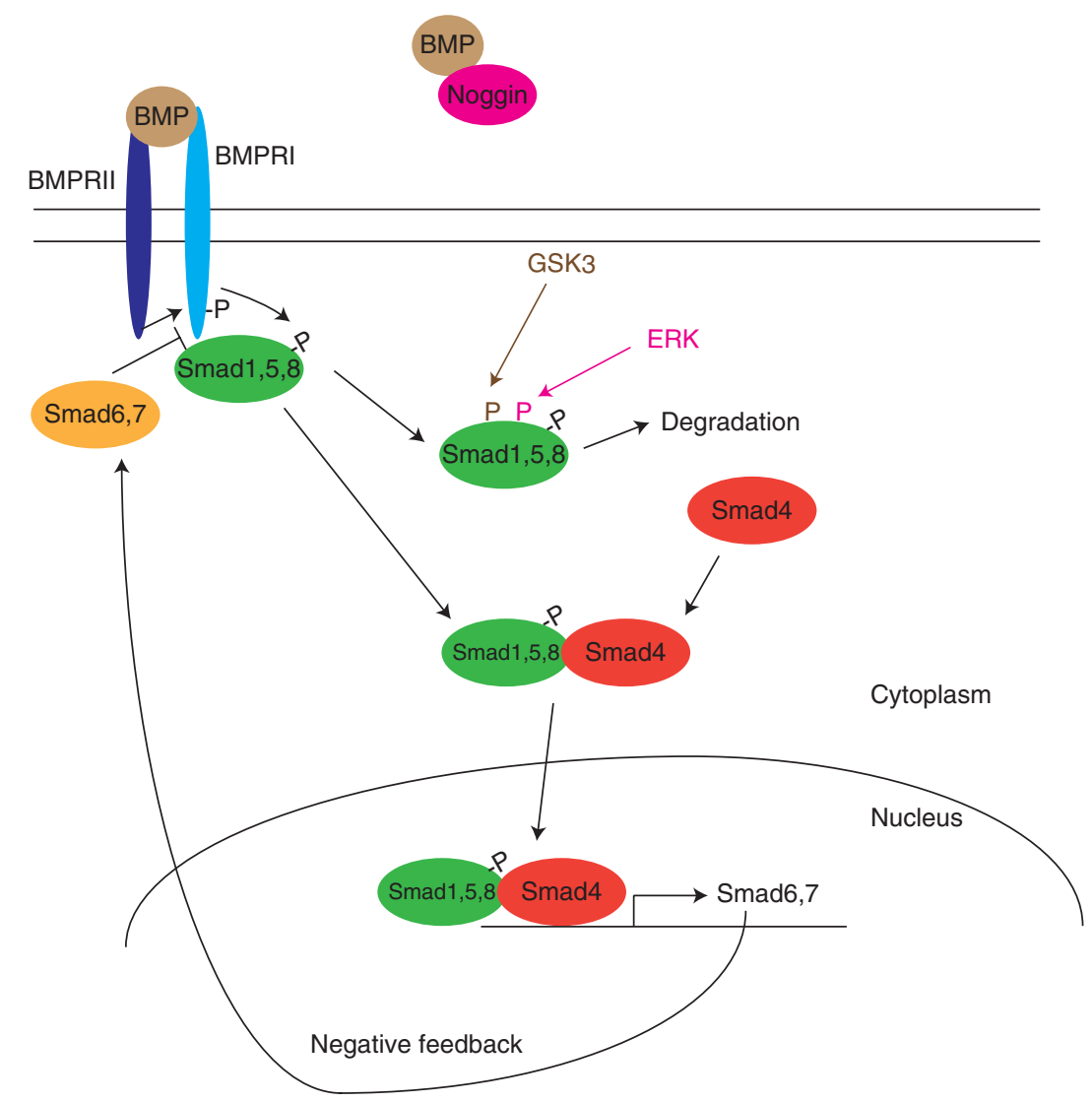

Figure 4. The BMP signaling pathway and regulation of SMAD activity. Binding of BMP ligand to BMPRII results in dimerization with BMPRI and phosphorylation of receptor (R-)Smads (Smad1, 5, or 8) close to the carboxyl terminus. These activated R-Smads complex with a Co-Smad (Smad4) and the Smad complex translocates to the nucleus where they interact with other transcriptional regulators to control gene transcription. Negative feedback mechanisms include the expression of SMAD6,7, which competes with SMAD1,5,8 for binding to BMPRI. Both WNT and RTK signaling pathways have been shown to inhibit BMP signaling at the level of Smad1. ERK phosphorylates the linker region in between the amino- and carboxy-terminal domains of Smad, which primes Smad for a further phosphorylation by GSK3. Dually phosphorylated Smad is targeted for degradation. Secreted BMP antagonists such as Noggin bind to and sequester BMP ligand in the extracellular space. 
Both class I and II receptors are required for the activity of BMPs in vivo (Mishina et al. 1995; Beppu et al. 2000). Seven type I receptors have been identified (Activin-like kinase [ALK]1-7). ALK1, ALK2, ALK3 (BMPR-IA), and ALK6 (BMPR-IB) activate signaling downstream from BMPs, whereas the other receptors (also referred to as T $\beta R I$ receptors) function downstream from other TGF $\beta$ ligands. Three type II receptors function as BMP receptors in mammals: BMPR-II, ActR-II, and ActR-IIB, with the former being specifically dedicated to BMPs (Yu et al. 2005; Miyazono et al. 2010). Several coreceptors and modulators have been described, which include glycosylphosphatidylinositol (GPI) -anchored proteins of the repulsive guidance molecule (RGM), DRAGON, SARA, and CD44 (Babitt et al. 2005; Samad et al. 2005; Miyazono et al. 2010).

Some type I and II receptors may be present on the cell surface as homo- or heterodimers and ligand binding stabilizes and increases the formation of oligomers. The intracellular ser-thr kinase domain of the type II receptor is constitutively active and heterodimerization results in the transphosphorylation of type I receptors, which induces a conformational change and conversion to an activated type I receptor. These receptors phosphorylate receptor-regulated (R-SMADs) leading to their activation. SMAD1, -5 , and -8 function as R-SMADS downstream from BMP. Activated R-Smads, in complex with the Co-SMAD, SMAD4 translocate to the nucleus and alter gene expression. Despite the apparently central role of SMAD4 in BMP signal transduction, the deletion of Smad4 from the mouse embryo has shown that some developmental processes can proceed relatively unaffected in the absence of SMAD4 (Chu et al. 2004). SMADs regulate gene transcription by binding directly to GC-rich regulatory elements often in association with other transcriptional regulators such as Runx and MyoD (Miyazono et al. 2005).

\subsubsection{Notch Signaling}

Notch signaling is activated by the binding of transmembrane receptors of the Delta/Serrate and Jagged families to the transmembrane Notch receptor on adjacent cells (or in some cases on the same cell) (Fig. 5) (ArtavanisTsakonas and Muskavitch 2010). Notch activation results in its proteolytic cleavage that liberates the Notch intracellular domain (NICD) that translocates to the nucleus and alters gene expression. The enzymes required for Notch processing are obligatory for Notch signaling and mutations in these enzymes phenocopy Notch loss-offunction mutants (Weber et al. 2011). NICD regulate gene expression in association with transcriptional coactivators, notably the mammalian homolog of $\mathrm{Su}(\mathrm{H})$, RBP-JK (Oka et al. 1995). Key targets of Notch signaling are the
Hairy/enhancer of split (Hes) genes. Transcriptional regulators of the Hes family repress the expression of Notch ligands. Thus, activation of Notch signaling in a cell results in down-regulation of ligand expression, whereas the lack of Notch signaling results in up-regulation of the ligand. This feed-forward mechanism underlies the ability of Notch signaling to accentuate gene expression differences between neighboring cells in a process referred to as lateral inhibition. Notch-mediated lateral inhibition is required for binary cell fate decisions such as sensory versus supporting hair cell fate in the mammalian cochlea (Lanford et al. 1999). A crucial role for Notch signaling in maintaining stem cell fate by preventing the expression of neurogenic bHLH factors like Hes1 has been observed (de la Pompa et al. 1997; Basak and Taylor 2007; Kageyama et al. 2007). A fundamental mechanism that appears to regulate asymmetric cell divisions during stem cell self-renewal involves the asymmetric segregation of proteins like Numb, a Notch antagonist, during cell division (Gulino et al. 2010). A recent study shows that the cell polarity pathways regulated by Par proteins and the cellular machinery that controls the orientation of the cell spindle also engage the Notch signaling pathway as a downstream effector to control the balance between proliferation and differentiation (Williams et al. 2011).

In addition to its role in lateral inhibition, the Notch pathway is also required for conferring developmental competency, a role that appears to involve a process of lateral induction where Notch signaling promotes the expression of the Jag1 ligand (Daudet and Lewis 2005; Hartman et al. 2010).

\section{THE ESTABLISHMENT OF SIGNALING CENTERS IN THE EMBRYO}

A key feature of secreted morphogens that function during development is that their expression tends to be localized to discrete, specialized groups of cells referred to as signaling or organizing centers. Clearly, the mechanisms that establish these specialized regions in the embryo are of fundamental importance. One of the best-understood signaling centers is the mid-hindbrain or Isthmus organizer (IsO), which is established by the concerted action of several transcription factors. Once expression has been initiated, some of these factors, like Otx2 and Gbx2, have mutually repressive activities and are required for the formation of a sharp boundary (Joyner et al. 2000). Cross-regulatory gene expression networks at the IsO rapidly become autoregulatory to maintain stable patterns of gene expression (Wittmann et al. 2009). Understanding the mechanisms that establish and maintain these critical regions in the developing embryo may find important application in regenerative medicine. 

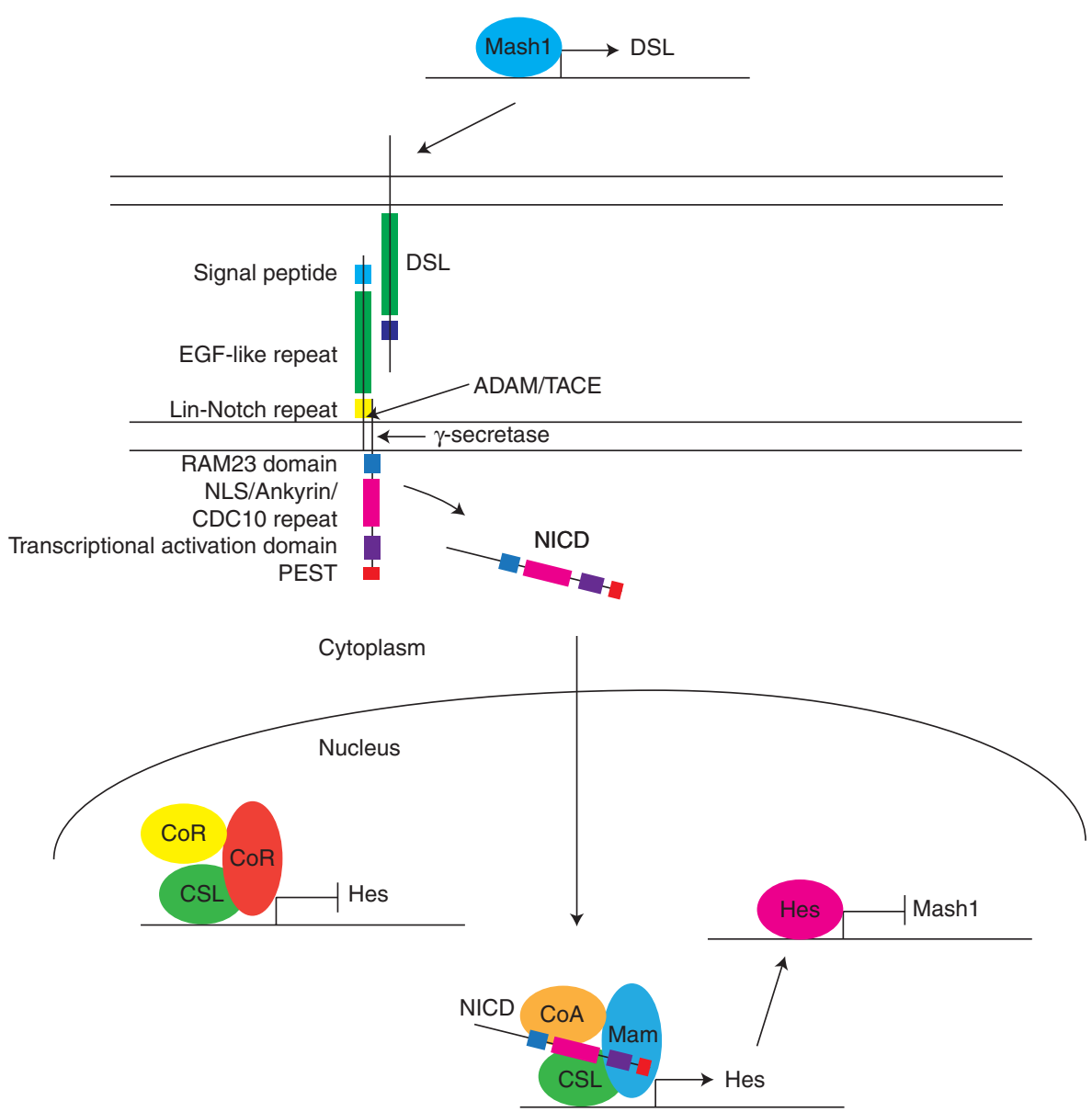

Figure 5. The Notch pathway. Binding of the extracellular domain of the Notch receptor to Delta and Serrate/ Jagged/LAG-2 (DSL) ligand on an adjacent cell induces a conformational change in Notch that exposes an extracellular ADAM10/TACE cleavage site. A subsequent intramembranous proteolytic cleavage by $\gamma$-secretase, releases the Notch intracellular domain (NICD), which translocates to the nucleus. NICD complexes with coactivators (CoA) and Mastermind (Mam) to replace corepressors (CoR) that occupy CBF1/Su(H)/LAG-1 (CSL)-bound Notch target gene promotors. An important group of target genes is the Hairy/enhancer of split (Hes) genes. Hes inhibits the expression of achaete-scute genes such as Ascl1 (Mash1) in cells receiving Notch signals. In cells not receiving Notch signals, Mash1 is expressed, which up-regulates the expression of Notch ligands (DSL).

\section{THE ORCHESTRATION OF CELL DIFFERENTIATION AND MORPHOGENESIS}

\subsection{Fundamental Cellular Processes}

A few key signaling pathways are used repeatedly during development to regulate many of the cellular processes that shape the developing embryo. A major challenge is to reveal how fundamental cellular processes such as proliferation, fate determination, differentiation, apoptosis, migration, adhesion, and cell shape changes are coordinated during morphogenesis. As it will be impossible to describe the role of each pathway in all developmental processes, I have summarized a few examples in Table 2 and will discuss specific examples that relate to fibroblast growth factor signaling.

\subsection{The Regulation of Proliferation by FGF Signaling}

The ras/MAPK pathway is well known for its ability to induce cell proliferation in embryonic cell types by controlling the expression of cell-cycle regulators (Srinivasan et al. 2009). Thus, an important function of FGF signaling is to promote the expansion of tissue progenitors. This role is shown particularly well during heart development. Cells that contribute to the developing heart are derived from different embryonic progenitor populations. The primary heart field provides cells to the left ventricle of the heart, whereas progenitors of the outflow tract and right ventricle are specified in the anterior or secondary heart field, SHF (Black 2007). FGF8 cell-autonomously controls the 
M.A. Basson

Table 2. Examples of fundamental cellular processes controlled by key developmental signaling pathways

\begin{tabular}{|c|c|c|c|}
\hline Signaling pathway & Process & Specific example & References \\
\hline \multirow{8}{*}{$\begin{array}{l}\text { Receptor tyrosine } \\
\text { kinase (RTK) }\end{array}$} & \multirow[t]{2}{*}{ Proliferation } & Chondrocytes & Liu et al. 2007 \\
\hline & & Anterior heart field & Ilagan 2006 \\
\hline & \multirow[t]{2}{*}{ Survival } & Anterior heart field & Ilagan 2006 \\
\hline & & Neural tube & Chi et al. 2003 \\
\hline & \multirow{2}{*}{ Cell fate determination } & Mesoderm & Ciruna and Rossant 2001 \\
\hline & & Cajal-Retzius cells & Zimmer et al. 2009 \\
\hline & Migration & $\begin{array}{l}\text { Directed migration of enteric } \\
\text { neuron precursors }\end{array}$ & Natarajan et al. 2002 \\
\hline & Proliferation & Cerebellar granule cell precursors & $\begin{array}{l}\text { Dahmane and Ruiz i Altaba } \\
\text { 1999; Wallace 1999; } \\
\text { Wechsler-Reya and Scott } \\
1999\end{array}$ \\
\hline \multirow[t]{4}{*}{ Hedgehog } & Survival & Lung development & White 2006 \\
\hline & Cell fate determination & Neural tube & Pringle 1996; Xu et al. 2010 \\
\hline & Migration & Neural crest-derived cells & Fu 2004; Tobin et al. 2008 \\
\hline & Proliferation & Skin stem cells & Horsley et al. 2008 \\
\hline \multirow[t]{4}{*}{ BMP } & Survival & Lung epithelium & Eblaghie et al. 2006 \\
\hline & Cell fate determination & Respiratory epithelium & Maier et al. 2010 \\
\hline & Migration & Cardiac neural crest & Kaartinen 2004 \\
\hline & Proliferation & Smooth muscle cells & El-Bizri et al. 2008 \\
\hline \multirow[t]{2}{*}{ WNT } & Survival & $\begin{array}{l}\text { Telencephalon (indirectly } \\
\text { through FGF) }\end{array}$ & Paek et al. 2011 \\
\hline & Cell fate determination & Lung progenitors & Goss et al. 2009 \\
\hline \multirow{5}{*}{ Notch } & Proliferation & Cerebellar granule cell precursors & Solecki et al. 2001 \\
\hline & Survival & Bergmann glia & Weller et al. 2006 \\
\hline & Cell fate determination & Intestine & Stanger 2005 \\
\hline & & Nephron & Cheng et al. 2007 \\
\hline & Migration & Second heart field (indirect) & High et al. 2009 \\
\hline \multirow[t]{3}{*}{ Retinoic acid } & Proliferation & Forebrain & Ribes et al. 2006 \\
\hline & Survival & Limb bud & Yashiro et al. 2004 \\
\hline & Cell fate determination & Germ cells & Bowles et al. 2010 \\
\hline
\end{tabular}

Abbreviations: BMP, bone morphogenetic protein; WNT, wingless; FGF, fibroblast growth factor.

expansion of the SHF population in the early embryo, and Fgf8 hypomorphic embryos show truncations of the outflow tract and right ventricle (Ilagan 2006; Park et al. 2006). These types of cardiovascular defects are characteristic of DiGeorge and Alagille syndromes and Fgf8 expression is reduced in mouse models of these syndromes, confirming the importance of maintaining appropriate levels of FGF signaling to prevent developmental anomalies (High et al. 2009; Vitelli et al. 2010).

In addition to merely increasing the size of an organ or a specific population of precursor cells, more sophisticated control of the orientations of cell divisions in a developing tissue may underlie anisotropic growth and the formation of organs and tissues with a defined three-dimensional structure. Indeed, studies have shown that oriented cell divisions occur, for example, during the elongation of epithelial tubes and the outgrowth of appendages (Boehm et al. 2010; Wyngaarden et al. 2010). Mutations that affect PCP pathways have now been shown to alter the orientation of cell divisions in developing tissues (Saburi et al. 2008; Karner et al. 2009; Matsuyama et al. 2009; Li et al. 2011). Recent evidence shows that hyperactivation of the FGF pathway by removal of Sprouty antagonists in the embryonic lung epithelium, also results in the disruption of oriented cell division (Tang et al. 2011). The mechanisms whereby deregulated ras/MAPK signaling control or alter mitotic spindle orientation still need to be elucidated.

\subsection{Cell Fate Determination by FGF Signaling}

The establishment and maintenance of distinct cell identities are ultimately controlled by epigenetic mechanisms: the stable expression of defined transcriptional networks. How cell fates are initially determined during embryogenesis by establishing different transcription factor profiles in different groups of progenitors remains an important question. Perhaps the best-studied system in this context is the specification of different neuronal identities in the neural tube as a 
function of SHH signal strength and duration (Ruiz i Altaba et al. 2003; Dessaud et al. 2007; Ulloa and Briscoe 2007).

RTK signaling has been shown to determine cell fate in several contexts. One of the best-known functions of FGF signaling in the early embryo is the specification of mesoderm during gastrulation. In addition to being required for the migration of cells away from the primitive streak, FGF8 signaling through FGFR1 controls mesoderm formation through regulating the expression of $T$ (Brachyury) and Tbx6 genes (Sun et al. 1999; Ciruna and Rossant 2001; Guo and Li 2007).

Another well-studied example of FGF signals being involved in cell fate determination is that of commitment of cells in the cranial ectoderm to the otic fate. In the mouse, several FGF ligands function redundantly in this process (Mahmood et al. 1996; McKay 1996; Alvarez et al. 2003; Wright and Mansour 2003; Ladher et al. 2005). Importantly, cross-regulation between FGF and WNT signals during this process restricts otic fate induction to a defined position in the embryo (Urness et al. 2010).

Recently, the Grove laboratory has shown that the fate of neuroepithelial cells in the embryonic cortex is determined by their distance from the source of FGF8 in the commissural plate, an important signaling center (Toyoda et al. 2010). This study shows that FGF8 can indeed function as a secreted morphogen to determine cell fate along the anterior-posterior axis of the telencephalon. These findings clearly have important implications for neurodevelopmental disorders associated with altered levels of signaling.

\subsection{Cell Survival}

Many (if not most) cells in the developing embryo are actively being kept alive by specific signals. Thus, the function of a particular signaling pathway in cell survival is only revealed by increased apoptosis on the loss or inhibition of this pathway. Studies over the last few years have identified several contexts in which FGF signals protect cells from apoptosis. The conditional deletion of Fgf8 in the IsO results in massive cell death shortly after the withdrawal of the FGF8 signal (Chi et al. 2003). When FGF signaling is not completely lost but only reduced, cell death first becomes apparent in cells furthest away from the $\mathrm{IsO}$, the source of survival signal. These observations suggest that cell death only occurs when FGF signaling drops below a certain threshold (Basson et al. 2008). A similar observation has been made during limb development where a reduction in FGF production from the distal tip results in cell death in the proximal limb bud (Sun et al. 2002). A recent set of elegant experiments by the Hébert laboratory shows that FGF signals produced by a forebrain signaling center also protects cells in the telencephalon from apoptosis. In this case, FGF expression is regulated by $\mathrm{WNT} / \beta$-catenin signaling and the antiapoptotic effects of FGF signaling mediated through the inhibition of proapoptotic signals downstream from BMP/SMAD4 signaling (Paek et al. 2009, 2011).

The regulated withdrawal of a survival factor can be used to shape developing structures. An excellent example is that of interdigital cell death during limb development, a process required for the complete physical separation of the developing digits from each other. A recent study showed that high FGF8 signaling in the distal limb bud protects cells from apoptosis, despite the RA-induced expression of cell death molecules such as Bax2. However, as digits begin to appear, Fgf8 expression is gradually down-regulated in the interdigital regions, and this withdrawal of FGF signaling allows the progression of apoptosis (Hernandez-Martinez et al. 2009). Consistent with these findings, an upregulation of FGF4 and FGF8 expression on the deletion of BMPR1a from the AER was found to result in interdigital webbing (Pajni-Underwood et al. 2007).

FGF signaling activates the PI3K pathway in cells, which has been implicated in cell survival, especially in the context of cancer (Turner and Grose 2010). The activation of PI3K signaling is required for the survival of epiblast cells in embryoid bodies and the blastocyst (Halet et al. 2008; He et al. 2010). However, in vitro studies suggest that both the ras/MAPK and PI3K pathways control cell survival in a context-dependent manner (Chavarría et al. 2007). Whether PI3K is obligatory for the transduction of survival signals downstream from FGF and to what extent deregulated PI3K signaling is directly involved in apoptosis on FGF withdrawal in the embryo is not known.

\subsection{Cell Adhesion and Migration}

In addition to a role in specifying mesodermal fate during gastrulation, FGF8 signaling is also required for the epithelial-to-mesenchymal transition and migration of mesodermal cells. This transition is associated with the loss of Ecadherin expression and the loss of cell adhesion (Ciruna and Rossant 2001). FGF signaling has been implicated in cell migration in several other contexts in the developing mouse (Colvin et al. 2001; Lin et al. 2009).

\subsection{Cell Differentiation}

The final stages of cellular differentiation are intimately linked with withdrawal from the cell cycle (Das et al. 2009; Yu et al. 2011), and are often associated with distinct alterations in the shape of cells. For example, the striking elongation of lens fibers during their terminal differentiation in the eye is controlled by FGF signaling, in coordination with other pathways such as WNT and TGFß (Lovicu and 
McAvoy 2005; Zhao et al. 2008). Recently, specific FGF ligands have been shown to regulate the formation of different types of synapses during neuronal differentiation (Terauchi et al. 2010). The mechanisms that underlie this subtle, yet extremely important role of FGF signaling in cell differentiation remains poorly understood (Jones and Basson 2010).

\section{SIGNAL STRENGTH AND DURATION: INTERPRETATION AND REGULATION}

The cellular response to a particular signal is dependent on cellular context, the strength and duration of the signal. The difference between a RTK signal that results in cell proliferation versus a signal appropriate for differentiation may be relatively subtle (Marshall 1995; Pellegrino and Stork 2006). However, small differences in the initial signal can become amplified as signals are transmitted down the signaling cascade over time. Understanding how cells interpret signals with slightly different intensities or durationsignals that are quantitatively different- to produce qualitatively different responses such as fate or lineage choice, is key to grasping the mechanisms behind cell fate determination during development. An elegant mechanism that applies to RTK signaling and one that enables cells to distinguish between short-lived versus sustained RTK signals involves the regulation of the transcription factor, c-fos. The essence of this mechanism lies in the multilevel regulation of c-fos by ERK signaling (Fig. 1). Firstly, the $c$-fos gene is a direct, immediate-early transcriptional target of ERK signaling (Gille et al. 1992; Hipskind et al. 1994). However, the c-fos protein is relatively unstable and is rapidly degraded. ERK-mediated phosphorylation of c-fos on serine residues stabilizes c-fos and primes it for additional ERK phosphorylation that further enhances its transcriptional activity (Okazaki and Sagata 1995; Ferrara et al. 2003; Monje et al. 2003). Thus, a transient RTK signal will only result in short-lived c-fos activity that does not lead to significant induction of downstream gene expression. Sustained ERK activation, in contrast, results in the accumulation of active c-fos. Thus, c-fos acts as an important sensor for the duration of ERK signaling in cells (Pellegrino and Stork 2006).

\subsection{Feedback Regulation of RTK Signaling Pathways}

Many of the secreted signaling molecules produced in the developing embryo function as morphogens, where different concentrations of these factors have distinct effects on cell fate. Positive and negative feedback mechanisms are essential to maintain appropriate levels of signaling. In addition, they are used by the embryo to interpret small differences in signal intensity or duration and effectively turn these into developmental switches.

\subsubsection{Positive Feedback}

An increased expression of ligand or receptor, which can enhance signaling in an autocrine fashion is a positive feedback mechanism often observed in cancer (Schulze 2004; Hynes and Schlange 2006). Examples of paracrine positive feedback mechanisms abound in the developing embryo. For example, reciprocal signaling between epithelial and mesenchymal cells is central to organogenesis and stem/progenitor cell maintenance; often mediated by combinations of epithelially and mesenchymally expressed FGF ligands and receptors. These tend to form positive feedback loops such that increased FGF signaling in one tissue results in the upregulation of FGF ligands, which then signals back at increased intensity to the other tissue. Negative feedback mechanisms are often used to disrupt these feed-forward mechanisms, and the removal of negative regulators can have drastic consequences on development (Klein et al. 2008).

Positive feedback provides a feasible mechanism to explain the different effects of NGF or EGF on PC12 cells, which has served as an in vitro model for how different signal intensities are translated into distinct cell fates. Santos et al. showed that NGF, but not EGF stimulation, induces a positive-feedback loop from MAPK to Raf (Santos et al. 2007). A striking example of how positive feedback can dramatically modulate RTK signaling kinetics has been reported in Xenopus oocytes, where ERK activation induces a strong positive-feedback loop mediated by Mos. As a result, ERK activation and downstream effects in these cells are bimodal: either OFF or ON (Ferrell and Machleder 1998). In agreement with the findings in Xenopus, $\mathrm{Mos}^{-/-}$ mouse oocytes do not activate MAPK during meiosis and are associated with metaphase II arrest (Choi et al. 1996). Thus, positive-feedback mechanisms allow cells to distinguish between different growth factors and are used by cells to turn differences in signal strength or duration into distinct developmental switches that ensure robust responses to secreted morphogens during embryonic development (Freeman 2000).

\subsubsection{Negative Feedback}

Several negative-feedback mechanisms that limit the strength, duration, and/or range of growth factor signaling during development have been described. Signaling molecules like PKC can directly modify EGF receptors rendering them unable to bind ligand with high affinity (Lin et al. 1986), a mechanism that may allow for transmodulation between different receptors (Ullrich and Schlessinger 1990). The recruitment and activation of molecules such as $\mathrm{Cbl}$ with ubiquitin ligase activity catalyzes receptor ubiquitination, internalization, and subsequent degradation, resulting in the rapid removal of activated RTKs from the cell 
surface (Sorkin and Goh 2009; Zwang and Yarden 2009). Slightly slower mechanisms involve the induction of new feedback regulators such as those that can bind to and sequester ligand or prevent a productive ligand-receptor interaction. Other intracellular molecules that can interfere with intracellular signal transduction include members of the Sef, Spred, and Sprouty families of proteins (Mason et al. 2006; Bundschu et al. 2007; Ron et al. 2008), MAPK phosphatases (Dickinson and Keyse 2006), transcriptional repressors, and RNA-binding proteins (Amit et al. 2007).

Elegant studies in Xenopus have shown that the superimposition of specific feedback mechanisms that target certain downstream signaling cascades more effectively than others can switch and fine-tune the cellular response in certain contexts (Sivak et al. 2005). In the mouse, these same negative-feedback mechanisms restrict signaling to small, discrete regions in developing organs (Basson et al. 2005), which allows exquisite control of cell-fate decisions, even at the cellular level (Shim et al. 2005).

Taken together, a combination of mechanisms that alter the dynamics and stability of signaling complexes, induction of positive- and negative-feedback loops and stabilization of transcription factors are all involved in translating slightly different signaling properties to clear-cut differences in cellular responses (Kao 2001; Labalette et al. 2010).

\subsection{Regulators of Other Signaling Pathways}

Positive and negative regulators have been described for all the pathways discussed so far. During WNT signaling (Fig. 2), secreted Fz-related proteins (sFRPs) bind directly to WNT ligands to compete with $\mathrm{Fz}$ for binding or enhance the WNT signaling range (Rattner et al. 1997; Mii and Taira 2009). In keeping with the central function of LRP5/6 in $\mathrm{WNT} / \beta$-catenin signaling, several WNT coreceptors and inhibitors, R-spondin, Dickkopf (Dkk), Wise, and SOST have been reported to interact directly with LRP5/6 (Glinka et al. 1998; Mao et al. 2002; Itasaki et al. 2003; Li 2005; Semenov 2005; Kim et al. 2008).

A number of modulators of the SHH pathway has been described, including Cdo, Boc, LRP2 (Megalin), and Gas1 (McCarthy et al. 2002; Tenzen et al. 2006; Allen et al. 2007; Murdoch and Copp 2010; Zhang et al. 2010). These molecules appear to bind to $\mathrm{SHH}$ and enhance $\mathrm{SHH}$ signaling, particularly at low doses of SHH (Allen et al. 2007). Feedback regulation of SHH signaling, especially through upregulation of Ptch1, is important during interpretation of the SHH gradient (Fig. 3) (Dessaud et al. 2007).

BMP signaling is regulated by extracellur antagonists (e.g., Noggin, Gremlin, Follistatin, and Chordin) that bind to BMPs and prevent them from activating receptors (Brunet et al. 1998; Khokha et al. 2003; Walsh et al. 2010). BMP activation also induces negative-feedback mechanisms like the expression of inhibitory (I-SMADs), SMAD6 and SMAD7, which bind to activated type I receptors and block their ability to activate R-SMADs (Goto et al. 2007). In addition, I-SMADs can form complexes with R-SMADS and prevent their activity (Fig. 4) (Zhang et al. 2007). I-SMADS also interact with Smad ubiquitin regulatory factors (Smurfs) and recruit these ubiquitin ligases to the receptors leading to receptor ubiquitination and degradation. Smurfs can also directly regulate the degradation of BMP-regulated SMAD1/5 (Murakami et al. 2003).

\section{INTEGRATING MULTIPLE SIGNALING PATHWAYS DURING DEVELOPMENT}

So far we have dealt with individual signaling pathways and discussed their roles in controlling cell behavior during embryonic development. This reductionist approach of focusing on the function of a single pathway, process, or gene in the formation of a specific structure, is clearly essential for uncovering fundamental molecular mechanisms. At the same time, all biologists have to admit that the reality is more complex. We know that cells are exposed to, and respond to several signaling pathways simultaneously or consecutively and somehow integrate all this information. A major challenge is to understand how cells integrate information in a developmental context and how the combined action of several signaling factors on a tissue drive the morphogenetic processes that eventually result in the creation of a fully functioning organism.

Many different examples of cross-regulation between different pathways have been described and a few examples are indicated in Figures 1-5. For example, the activation of AKT downstream from RTK signaling may enhance WNT/ $\beta$-catenin signaling by inhibiting GSK3 $\beta$, thus resulting in enhanced stability and activity of $\beta$-catenin (Baryawno et al. 2010). In the embryonic neural tube, WNT ligands in the roof plate control Gli3 expression that inhibits $\mathrm{SHH}$ target gene expression in the dorsal neural tube (Alvarez-Medina et al. 2008). Several examples of cross-talk existng between Notch and RTK signaling have been described in Drosophila (Hurlbut et al. 2009). Furthermore, important downstream targets of the Notch pathway such as Hes-related genes are also regulated by other pathways such as WNT (Kubo and Nakagawa 2009).

The emerging field of "systems biology" aims to answer the question of how different molecules and pathways are interlinked and affect each other within the same system. Diagrams that provide a single view of these interactions are useful for the interpretation of experimental results or predicting the possible outcomes of perturbations. However, the importance of some interactions may be of significance 
to some developmental processes or time points and not to others. Furthermore, many interactions important in developmental biology are non-cell-autonomous, i.e., involve intercellular communication. This means that each of these interactions will have to be validated, and the relevance or impact assessed on a chosen cellular process. To understand how signaling information is integrated during development, a representative signaling network might eventually need to incorporate both intra- and intercellular signals in each cell population at every developmental time point.

\subsection{Intracellular Signaling Molecules that Integrate Different Signaling Pathways}

It has been observed that some molecules appear as "nodes" in protein interaction networks (Pieroni et al. 2008). Such molecules are expected to function as important integrators of multiple signaling pathways. Understanding the molecular mechanisms whereby the activity of these important molecules is regulated is therefore a crucial step toward understanding signal integration at the molecular level.

Perhaps the best-studied example of signal integration at the level of a single molecule is that of SMAD1, a mediator of BMP signals during development (Fig. 4). BMP signaling induces the phosphorylation of SMAD1 on carboxy-terminal residues that promotes the nuclear translocation of SMAD1. SMAD1 contains a "linker" region in the middle of the protein in between the amino- and carboxyterminal halves. This linker region has a number of residues that are reversibly modified by other signaling cascades. Phosphorylation by ERK and GSK3 enhances the proteasomal degradation of SMAD1 by SMURF1 (Aubin et al. 2004; Sapkota et al. 2007). Thus, the FGF/ras/MAP kinase pathway can antagonize BMP signals, whereas canonical WNT signaling enhances BMP signaling by preventing the GSK3-mediated SMAD1 phosphorylation (Fuentealba et al. 2007; Eivers et al. 2008). Recently, RA was also shown to interfere with BMP signaling at the level of SMAD1 by augmenting MAPK activation (Sheng et al. 2010). Thus, a picture is emerging whereby SMAD1 is not only devoted to transducing BMP signals to the nucleus, but an essential node onto which a variety of signaling cascades converge.

\subsection{Integrating Signals to Coordinate the Behavior of Cell Populations}

In addition to considering how two pathways directly intersect in the same cell, one can also consider a situation where the independent effects of separate signaling pathways on a population of cells result in the emergence of a complex morphogenetic process. An excellent example of this has been described in the developing limb bud.
The first morphogenetic process in the formation of a limb is the outgrowth of the limb bud along its proximaldistal axis. Both FGF and WNT signals have been implicated in this process and mutations that affect FGF8 and WNT5a expression are associated with malformed, shorter limbs (Yamaguchi et al. 1999; Lewandoski et al. 2000; Moon et al. 2000). Exactly how these factors control limb outgrowth and how these individual roles relate to each other has remained a mystery. Cell proliferation is an obvious requirement for growth, but studies suggest that anisotropic growth is not achieved by different levels of proliferation across the bud. Instead, mesenchymal cells within the limb bud are polarized and cell division and migration within the developing limb bud are nonrandom (Boehm et al. 2010; Gros et al. 2010). Gros et al. combined a powerful genetic method for marking a small number of cells randomly with green fluorescent protein (GFP) with time-lapse imaging, and found that cells in the ventral and dorsal regions of Wnt $5 a$-deficient limb buds lost their directed movement toward the ectoderm. The reintroduction of WNT5a into mutant buds regained their coherent movement. Experiments with pharmacological inhibitors showed that activation of the JNK signaling pathway was required for the oriented cell divisions. In contrast, an inhibition of the FGF/ras/MAPK pathway did not affect oriented cell division, but reduced the velocity of cell movement. Conversely, activating this pathway by expressing constitutively active MEK1 or applying FGF8, increased cell movement. These experimental effects fit well with the correlation between ERK activity and cell movement in the normal limb bud, where both are highest closest to the source of FGF signals in the ectoderm. Interestingly, modulation of WNT/JNK signaling did not affect the velocity of cell movement and alterations in FGF/MAPK signaling did not alter the orientation of cell division. Based on these findings the investigators proposed that the combined activity of these two pathways drives the anisotropic growth of the limb bud (Gros et al. 2010).

\section{MECHANICAL BIOLOGY AND MORPHOGENESIS}

A crucial question that remains is the following: How do these morphogens and signaling pathways physically control morphogenesis, i.e., how are these signals transformed to specific forces that shape tissues during their formation? Mammoto and Ingber recently referred to the classical treatise by D'Arcy Thompson "On Growth and Form" in which it was suggested that patterns are "diagrams of underlying forces" (Thompson 1917; Mammoto and Ingber 2010). The emerging field of "mechanical biology" tries to address this question head-on and lies at the interface of modern developmental biology, engineering, and physics. 
A variety of mechanical forces play important roles during development and some operate between the cytoskeleton and extracellular matrix to mediate the mechanical stabilization of cell shape. The signaling pathways most directly linked to mechanical changes in tissue are the PCP and rho/rac pathways. Activation of these pathways directly affects the mechanical forces across a tissue by modulating the cytoskeleton. The fundamental roles of PCP pathway components in processes such as neural tube closure clearly support this view (Wang and Nathans 2007). Several pathways that regulate PCP have been implicated in the elongation of epithelial tubules during kidney development. These pathways appear to function through effects on both convergent extension and oriented cell divisions (Saburi et al. 2008; Karner et al. 2009; Mao et al. 2011). Studies in Xenopus embryos have shown that the mechanical forces that drive convergent extension are mediated by Rho/ ROCK signals and myosin II effectors (Unterseher et al. 2004; Tanegashima et al. 2008). Mouse knockout studies have implicated signals through RhoA in directed cell migration, cell fate, and branching morphogenesis (Parker et al. 2002; Moore et al. 2005; Assoian and Klein 2008; Mammoto and Ingber 2009; Herzog et al. 2011). The correlation between the asymmetric localization of RTKs and polarized organization of rho/myosin II components in other developing tissues suggest that growth factor signaling, changes in the cytoskeleton, and mechanical forces may be intimately linked during morphogenesis (Sai and Ladher 2008).

Recently, evidence has started to emerge that shows that mechanical forces may themselves have direct effects on cell fate by activating downstream signaling cascades (Fig. 6)

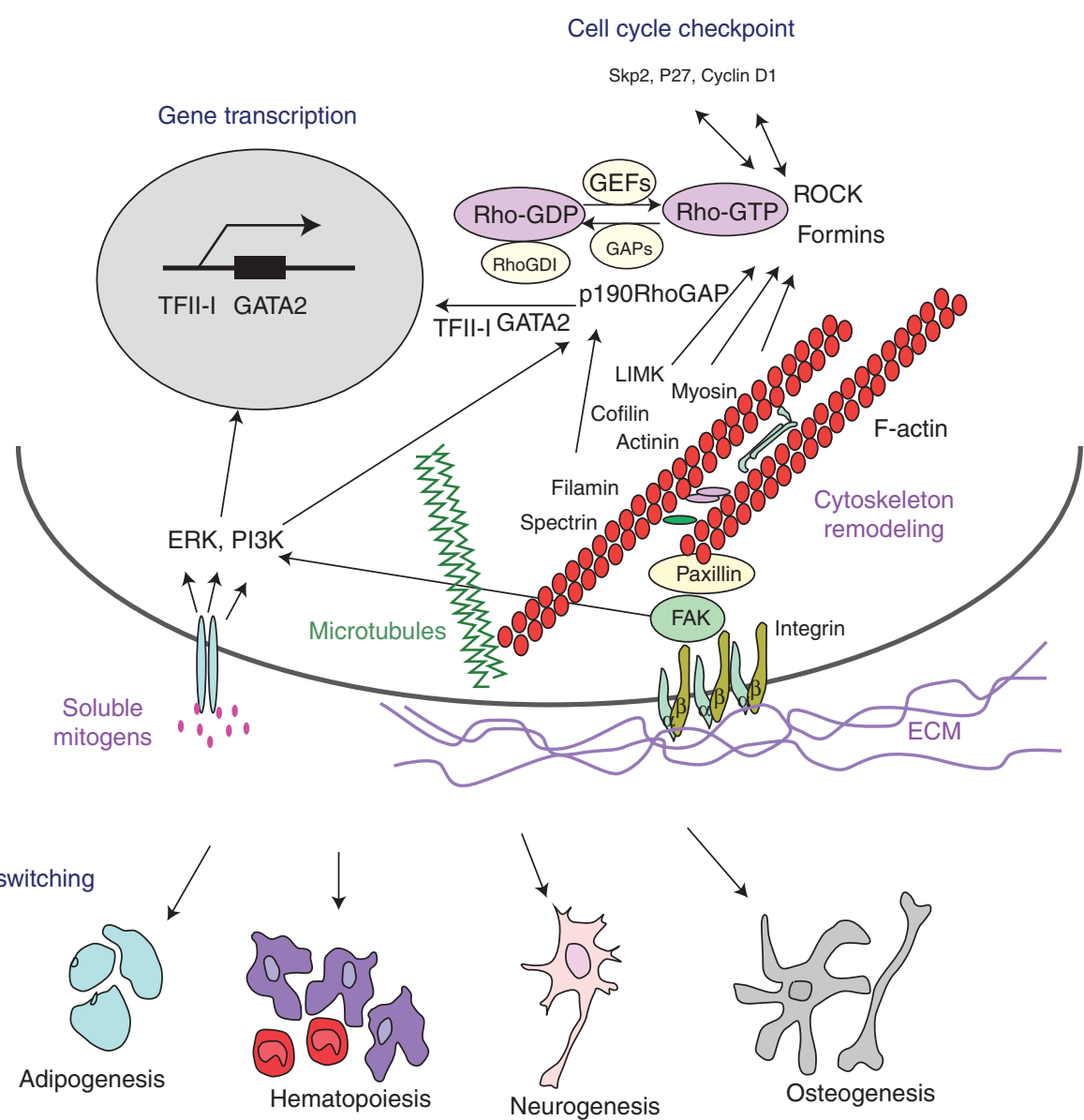

Figure 6. Schematic representation of cytoskeletal signals that control cell proliferation and fate. (Reproduced, with permission, from Mammoto and Ingber 2009.) Cell tethering to the ECM through integrins generate tension in the intracellular actin cytoskeleton. These changes can result in the activation of ERK and PI3K pathways, or the small GTPase Rho, through effects on FAK and p190RhoGAP, respectively. p190RhoGAP also modulates transcription by controlling the nuclear translocation of TFII-I and GATA2. Rho activation controls various cell-cycle regulators such as p27 and Cyclin D1. These combined effects on the cytoskeleton can alter the differentiation of multipotent stem/ progenitor cells. 
(Arnsdorf et al. 2009; Mammoto and Ingber 2009; Mammoto et al. 2009). In the context of embryonic development, mechanical shear forces generated by blood flow are important during cardiovascular development. The identification of signaling pathways activated by shear forces, their regulation, and downstream transcriptional regulators represents an exciting advance (Lee et al. 2006; Schmelter et al. 2006).

\section{CONCLUDING REMARKS}

In summary, understanding how cells respond to their environment and communicate with each other during embryonic development will require an integrated knowledge of secreted morphogens and other signaling molecules, their mechanism of action, the regulation and function of intracellular pathways, and a deep understanding of how these signals control fundamental biological processes such as oriented cell division, directed cell migration, and fate determination. Recent advances on the role of mechanical forces in morphogenesis and fate decisions are making important contributions to our quest to uncover the mechanisms that control embryonic development. Although much has been learned over the last few decades, many fascinating questions have also been raised by these discoveries. The successful combination of emerging systems and mechanical biological technologies with genetic manipulation in mouse embryos should lead to significant further advances in elucidating how genetic and epigenetic mechanisms control morphogenesis and cell fate.

\section{ACKNOWLEDGMENTS}

I want to express my gratitude to Mohi Ahmed, Philippa Francis-West, and Clemens Kiecker for comments on the manuscript. Where possible, reviews were cited and I apologize to researchers whose primary research publications could not be cited. Research in my laboratory is funded by the Wellcome Trust.

\section{REFERENCES}

Aberle H, Bauer A, Stappert J, Kispert A, Kemler R. 1997. $\beta$-Catenin is a target for the ubiquitin-proteasome pathway. EMBO J 16: $3797-$ 3804.

Airaksinen MS, Holm L, Hatinen T. 2006. Evolution of the GDNF family ligands and receptors. Brain Behav Evol 68: 181-190.

Allen BL, Tenzen T, McMahon AP. 2007. The Hedgehog-binding proteins Gas1 and Cdo cooperate to positively regulate Shh signalling during mouse development. Genes Dev 21: 1244-1257.

Alvarez Y, Alonso MT, Vendrell V, Zelarayan LC, Chamero P, Theil T, Bösl MR, Kato S, Maconochie M, Riethmacher D, et al. 2003. Requirements for FGF3 and FGF10 during inner ear formation. Development 130: $6329-6338$.

Alvarez-Medina R, Cayuso J, Okubo T, Takada S, Marti E. 2008. Wnt canonical pathway restricts graded Shh/Gli patterning activity through the regulation of Gli3 expression. Development 135: 237-247.
Amit I, Wides R, Yarden Y. 2007. Evolvable signalling networks of receptor tyrosine kinases: Relevance of robustness to malignancy and to cancer therapy. Mol Syst Biol 3: 151.

Andrae J, Gallini R, Betsholtz C. 2008. Role of platelet-derived growth factors in physiology and medicine. Genes Dev 22: 1276-1312.

Arnsdorf EJ, Tummala P, Kwon RY, Jacobs CR. 2009. Mechanically induced osteogenic differentiation-The role of RhoA, ROCKII and cytoskeletal dynamics. J Cell Sci 122: 546-553.

Artavanis-Tsakonas S, Muskavitch MA. 2010. Notch: The past, the present, and the future. Curr Top Dev Biol 92: 1-29.

Assoian RK, Klein EA. 2008. Growth control by intracellular tension and extracellular stiffness. Trends Cell Biol 18: 347-352.

Aubin J, Davy A, Soriano P. 2004. In vivo convergence of BMP and MAPK signaling pathways: Impact of differential Smad1 phosphorylation on development and homeostasis. Genes Dev 18: 1482-1494.

Babitt JL, Zhang Y, Samad TA, Xia Y, Tang J, Campagna JA, Schneyer AL, Woolf CJ, Lin HY. 2005. Repulsive guidance molecule (RGMa), a DRAGON homologue, is a bone morphogenetic protein co-receptor. J Biol Chem 280: 29820-29827.

Baryawno N, Sveinbjornsson B, Eksborg S, Chen CS, Kogner P, Johnsen JI. 2010. Small-molecule inhibitors of phosphatidylinositol 3-kinase/ Akt signaling inhibit Wnt $/ \beta$-catenin pathway cross-talk and suppress medulloblastoma growth. Cancer Res 70: 266-276.

Basak O, Taylor V. 2007. Identification of self-replicating multipotent progenitors in the embryonic nervous system by high Notch activity and Hes5 expression. Eur J Neurosci 25: 1006-1022.

Basson MA, Akbulut S, Watson-Johnson J, Simon R, Carroll TJ, Shakya R, Gross I, Martin GR, Lufkin T, McMahon AP, et al. 2005. Sproutyl is a critical regulator of GDNF/RET-mediated kidney induction. Dev Cell 8: 229-239.

Basson MA, Echevarria D, Ahn CP, Sudarov A, Joyner AL, Mason IJ, Martinez S, Martin GR. 2008. Specific regions within the embryonic midbrain and cerebellum require different levels of FGF signaling during development. Development 135: 889-898.

Behesti H, Holt JK, Sowden JC. 2006. The level of BMP4 signaling is critical for the regulation of distinct T-box gene expression domains and growth along the dorso-ventral axis of the optic cup. BMC Dev Biol 6: 62.

Beppu H, Kawabata M, Hamamoto T, Chytil A, Minowa O, Noda T, Miyazono K. 2000. BMP type II receptor is required for gastrulation and early development of mouse embryos. Dev Biol 221: 249-258.

Bhanot P, Brink M, Samos CH, Hsieh JC, Wang Y, Macke JP, Andrew D, Nathans J, Nusse R. 1996. A new member of the frizzled family from Drosophila functions as a Wingless receptor. Nature 382: 225-230.

Black BL. 2007. Transcriptional pathways in second heart field development. Semin Cell Dev Biol 18: 67-76.

Boehm B, Westerberg H, Lesnicar-Pucko G, Raja S, Rautschka M, Cotterell J, Swoger J, Sharpe J. 2010. The role of spatially controlled cell proliferation in limb bud morphogenesis. PLoS Biol 8: e1000420.

Bowles J, Feng C-W, Spiller C, Davidson T-L, Jackson A, Koopman P. 2010. FGF9 suppresses meiosis and promotes male germ cell fate in mice. Dev Cell 19: 440-449.

Bradley EW, Drissi MH. 2011. Wnt5b regulates mesenchymal cell aggregation and chondrocyte differentiation through the planar cell polarity pathway. J Cell Physiol 226: 1683-1693.

Brunet LJ, McMahon JA, McMahon AP, Harland RM. 1998. Noggin, cartilage morphogenesis, and joint formation in the mammalian skeleton. Science 280: 1455-1457.

Bundschu K, Walter U, Schuh K. 2007. Getting a first clue about SPRED functions. BioEssays 29: 897-907.

Burn SF, Webb A, Berry RL, Davies JA, Ferrer-Vaquer A, Hadjantonakis AK, Hastie ND, Hohenstein P. 2011. Calcium/NFAT signalling promotes early nephrogenesis. Dev Biol 352: 288-298.

Chavarría T, Valenciano AI, Mayordomo R, Egea J, Comella JX, Hallböök F, de Pablo F, de la Rosa EJ. 2007. Differential, age-dependent MEKERK and PI3K-Akt activation by insulin acting as a survival factor during embryonic retinal development. Dev Neurobiol 67: 1777-1788. 
Cheng HT, Kim M, Valerius MT, Surendran K, Schuster-Gossler K, Gossler A, McMahon AP, Kopan R. 2007. Notch2, but not Notch1, is required for proximal fate acquisition in the mammalian nephron. Development 134: 801-811.

Chi CL, Martinez S, Wurst W, Martin GR. 2003. The isthmic organizer signal FGF8 is required for cell survival in the prospective midbrain and cerebellum. Development 130: 2633-2644.

Chiang C, Litingtung Y, Lee E, Young KE, Corden JL, Westphal H, Beachy PA. 1996. Cyclopia and defective axial patterning in mice lacking Sonic hedgehog gene function. Nature 383: 407-413.

Choi T, Fukasawa K, Zhou R, Tessarollo L, Borror K, Resau J, Vande Woude GF. 1996. The Mos/mitogen-activated protein kinase (MAPK) pathway regulates the size and degradation of the first polar body in maturing mouse oocytes. Proc Natl Acad Sci 93: 7032-7035.

Chu GC, Dunn NR, Anderson DC, Oxburgh L, Robertson EJ. 2004. Differential requirements for Smad4 in TGF $\beta$-dependent patterning of the early mouse embryo. Development 131: 3501-3512.

Ciruna B, Rossant J. 2001. FGF signaling regulates mesoderm cell fate specification and morphogenetic movement at the primitive streak. Dev Cell 1: 37-49.

Clevers H. 2006. Wnt/ $\beta$-catenin signaling in development and disease. Cell 127: 469-480.

Cohen ED, Tian Y, Morrisey EE. 2008. Wnt signaling: An essential regulator of cardiovascular differentiation, morphogenesis and progenitor self-renewal. Development 135: 789-798.

Colvin JS, Green RP, Schmahl J, Capel B, Ornitz DM. 2001. Male-tofemale sex reversal in mice lacking fibroblast growth factor 9. Cell 104: $875-889$.

Dahmane N, Ruiz i Altaba A. 1999. Sonic hedgehog regulates the growth and patterning of the cerebellum. Development 126: 3089-3100.

Daniels MA, Teixeiro E, Gill J, Hausmann B, Roubaty D, Holmberg K, Werlen G, Holländer GA, Gascoigne NRJ, Palmer E. 2006. Thymic selection threshold defined by compartmentalization of Ras/MAPK signalling. Nature 444: 724-729.

Das G, Choi Y, Sicinski P, Levine EM. 2009. Cyclin D1 fine-tunes the neurogenic output of embryonic retinal progenitor cells. Neural Dev 4: 15.

Daudet N, Lewis J. 2005. Two contrasting roles for Notch activity in chick inner ear development: Specification of prosensory patches and lateral inhibition of hair-cell differentiation. Development 132: 541-551.

Davidson G, Wu W, Shen J, Bilic J, Fenger U, Stannek P, Glinka A, Niehrs C. 2005. Casein kinase $1 \gamma$ couples Wnt receptor activation to cytoplasmic signal transduction. Nat Cell Biol 438: 867-872.

de la Pompa JL, Wakeham A, Correia KM, Samper E, Brown S, Aguilera RJ, Nakano T, Honjo T, Mak TW, Rossant J, et al. 1997. Conservation of the Notch signalling pathway in mammalian neurogenesis. Development 124: 1139-1148.

Dessaud E, Yang LL, Hill K, Cox B, Ulloa F, Ribeiro A, Mynett A, Novitch BG, Briscoe J. 2007. Interpretation of the sonic hedgehog morphogen gradient by a temporal adaptation mechanism. Nature 450: 717-720.

Deyev IE, Sohet F, Vassilenko KP, Serova OV, Popova NV, Zozulya SA, Burova EB, Houillier P, Rzhevsky DI, Berchatova AA, et al. 2011. Insulin receptor-related receptor as an extracellular alkali sensor. Cell Metab 13: 679-689.

Dickinson RJ, Keyse SM. 2006. Diverse physiological functions for dualspecificity MAP kinase phosphatases. J Cell Sci 119: 4607-4615.

Dressler GR. 2006. The cellular basis of kidney development. Annu Rev Cell Dev Biol 22: 509-529.

Eblaghie MC, Reedy M, Oliver T, Mishina Y, Hogan BLM. 2006. Evidence that autocrine signaling through Bmprla regulates the proliferation, survival and morphogenetic behavior of distal lung epithelial cells. Dev Biol 291: 67-82.

Eivers E, Fuentealba LC, De Robertis EM. 2008. Integrating positional information at the level of Smad1/5/8. Curr Opin Genet Dev 18: 304-310.

El-Bizri N, Guignabert C, Wang L, Cheng A, Stankunas K, Chang CP, Mishina Y, Rabinovitch M. 2008. SM22 $\alpha$-targeted deletion of bone morphogenetic protein receptor $1 \mathrm{~A}$ in mice impairs cardiac and vascular development, and influences organogenesis. Development 135: $2981-2991$.

Favelyukis S, Till JH, Hubbard SR, Miller WT. 2001. Structure and autoregulation of the insulin-like growth factor 1 receptor kinase. Nat Struct Biol 8: 1058-1063.

Fehrenbacher N, Philips M. 2009. Intracellular signaling: Peripatetic Ras. Curr Biol 19: R454-R457.

Ferrara P, Andermarcher E, Bossis G, Acquaviva C, Brockly F, JarielEncontre I, Piechaczyk M. 2003. The structural determinants responsible for c-Fos protein proteasomal degradation differ according to the conditions of expression. Oncogene 22: 1461-1474.

Ferrell JE, Machleder EM. 1998. The biochemical basis of an all-or-none cell fate switch in Xenopus oocytes. Science 280: 895-898.

Freeman M. 2000. Feedback control of intercellular signalling in development. Nature 408: 313-319.

Fu M. 2004. Sonic hedgehog regulates the proliferation, differentiation, and migration of enteric neural crest cells in gut. J Cell Biol 166: 673-684.

Fuentealba LC, Eivers E, Ikeda A, Hurtado C, Kuroda H, Pera EM, De Robertis EM. 2007. Integrating patterning signals: Wnt/GSK3 regulates the duration of the BMP/Smad1 signal. Cell 131: 980-993.

Furdui CM, Lew ED, Schlessinger J, Anderson KS. 2006. Autophosphorylation of FGFR1 kinase is mediated by a sequential and precisely ordered reaction. Mol Cell 21: 711-717.

Gao B, Song H, Bishop K, Elliot G, Garrett L, English MA, Andre P, Robinson J, Sood R, Minami Y, et al. 2011. Wnt signaling gradients establish planar cell polarity by inducing Vangl2 phosphorylation through Ror2. Dev Cell 20: 163-176.

Gille H, Sharrocks AD, Shaw PE. 1992. Phosphorylation of transcription factor p62TCF by MAP kinase stimulates ternary complex formation at c-fos promoter. Nature 358: 414-417.

Glinka A, Wu W, Delius H, Monaghan AP, Blumenstock C, Niehrs C. 1998. Dickkopf- 1 is a member of a new family of secreted proteins and functions in head induction. Nature 391: 357-362.

Gordon MD, Nusse R. 2006. Wnt signaling: Multiple pathways, multiple receptors, and multiple transcription factors. J Biol Chem 281: 2242922433.

Goss AM, Tian Y, Tsukiyama T, Cohen ED, Zhou D, Lu MM, Yamaguchi TP, Morrisey EE. 2009. Wnt $2 / 2 \mathrm{~b}$ and $\beta$-catenin signaling are necessary and sufficient to specify lung progenitors in the foregut. Dev Cell 17: 290-298.

Goto K, Kamiya Y, Imamura T, Miyazono K, Miyazawa K. 2007. Selective inhibitory effects of Smad6 on bone morphogenetic protein type I receptors. J Biol Chem 282: 20603-20611.

Gros J, Serralbo O, Marcelle C. 2008. WNT11 acts as a directional cue to organize the elongation of early muscle fibres. Nature 457: 589-593.

Gros J, Hu JK-H, Vinegoni C, Feruglio PF, Weissleder R, Tabin CJ. 2010. WNT5A/JNK and FGF/MAPK pathways regulate the cellular events shaping the vertebrate limb bud. Curr Biol 20: 1993-2002.

Gulino A, Di Marcotullio L, Screpanti I. 2010. The multiple functions of Numb. Exp Cell Res 316: 900-906.

Guo Q, Li JYH. 2007. Distinct functions of the major Fgf8 spliceform, Fgf8b, before and during mouse gastrulation. Development 134: 22512260.

Hadari YR, Gotoh N, Kouhara H, Lax I, Schlessinger J. 2001. Critical role for the docking-protein FRS2 $\alpha$ in FGF receptor-mediated signal transduction pathways. Proc Natl Acad Sci 98: 8578-8583.

Halet G, Viard P, Carroll J. 2008. Constitutive PtdIns(3,4,5)P3 synthesis promotes the development and survival of early mammalian embryos. Development 135: 425-429.

Hartman BH, Reh TA, Bermingham-McDonogh O. 2010. Notch signaling specifies prosensory domains via lateral induction in the developing mammalian inner ear. Proc Natl Acad Sci 107: 15792-15797.

Hayhurst M, McConnell SK. 2003. Mouse models of holoprosencephaly. Curr Opin Neurol 16: 135-141. 
He X, Liu J, Qi Y, Brakebusch C, Chrostek-Grashoff A, Edgar D, Yurchenco PD, Corbett SA, Lowry SF, Graham AM, et al. 2010. Rac1 is essential for basement membrane-dependent epiblast survival. Mol Cell Biol 30: 3569-3581.

Hernandez-Martinez R, Castro-Obregon S, Covarrubias L. 2009. Progressive interdigital cell death: Regulation by the antagonistic interaction between fibroblast growth factor 8 and retinoic acid. Development 136: 3669-3678.

Herzog D, Loetscher P, van Hengel J, Knüsel S, Brakebusch C, Taylor V, Suter U, Relvas JB. 2011. The small GTPase RhoA is required to maintain spinal cord neuroepithelium organization and the neural stem cell pool. J Neurosci 31: 5120-5130.

High FA, Jain R, Stoller JZ, Antonucci NB, Lu MM, Loomes KM, Kaestner KH, Pear WS, Epstein JA. 2009. Murine Jagged1/Notch signaling in the second heart field orchestrates Fgf8 expression and tissue-tissue interactions during outflow tract development. J Clin Invest 119: 1986-1996.

Hipskind RA, Baccarini M, Nordheim A. 1994. Transient activation of RAF-1, MEK, and ERK2 coincides kinetically with ternary complex factor phosphorylation and immediate-early gene promoter activity in vivo. Mol Cell Biol 14: 6219-6231.

Horsley V, Aliprantis AO, Polak L, Glimcher LH, Fuchs E. 2008. NFATc1 balances quiescence and proliferation of skin stem cells. Cell 132: $299-310$

Hurlbut GD, Kankel MW, Artavanis-Tsakonas S. 2009. Nodal points and complexity of Notch-Ras signal integration. Proc Natl Acad Sci 106: $2218-2223$.

Hynes NE, Schlange T. 2006. Targeting ADAMS and ERBBs in lung cancer. Cancer Cell 10: 7-11.

Ilagan R. 2006. Fgf8 is required for anterior heart field development. Development 133: 2435-2445.

Ingham PW. 2001. Hedgehog signaling in animal development: Paradigms and principles. Genes Dev 15: 3059-3087.

Itasaki N, Jones CM, Mercurio S, Rowe A, Domingos PM, Smith JC, Krumlauf R. 2003. Wise, a context-dependent activator and inhibitor of Wnt signalling. Development 130: 4295-4305.

Itoh N. 2010. Hormone-like (endocrine) Fgfs: Their evolutionary history and roles in development, metabolism, and disease. Cell Tissue Res 342: $1-11$.

Jacob L, Lum L. 2007. Deconstructing the hedgehog pathway in development and disease. Science 318: 66-68.

Jones K, Basson MA. 2010. FGF ligands emerge as potential specifiers of synaptic identity. Cell Sci 7: 33-42.

Joyner AL, Liu A, Millet S. 2000. Otx2, Gbx2 and Fgf8 interact to position and maintain a mid-hindbrain organizer. Curr Opin Cell Biol 12: $736-741$

Kaartinen V. 2004. Cardiac outflow tract defects in mice lacking ALK2 in neural crest cells. Development 131: 3481-3490.

Kageyama R, Ohtsuka T, Kobayashi T. 2007. The Hes gene family: Repressors and oscillators that orchestrate embryogenesis. Development 134: $1243-1251$.

Kao Sc. 2001. Identification of the mechanisms regulating the differential activation of the MAPK cascade by epidermal growth factor and nerve growth factor in PC12 cells. J Biol Chem 276: 18169-18177.

Karner CM, Chirumamilla R, Aoki S, Igarashi P, Wallingford JB, Carroll TJ. 2009. Wnt9b signaling regulates planar cell polarity and kidney tubule morphogenesis. Nat Genet 41: 793-799.

Kestler HA, Kühl M. 2008. From individual Wnt pathways towards a Wnt signalling network. Philos T Roy Soc B 363: 1333-1347.

Khokha MK, Hsu D, Brunet LJ, Dionne MS, Harland RM. 2003. Gremlin is the BMP antagonist required for maintenance of Shh and Fgf signals during limb patterning. Nat Genet 34: 303-307.

Kiecker C, Niehrs C. 2001. A morphogen gradient of Wnt/ $\beta$-catenin signalling regulates anteroposterior neural patterning in Xenopus. Development 128: $4189-4201$.

Kim K-A, Wagle M, Tran K, Zhan X, Dixon MA, Liu S, Gros D, Korver W, Yonkovich S, Tomasevic N, et al. 2008. R-Spondin family members regulate the Wnt pathway by a common mechanism. Mol Biol Cell 19: $2588-2596$.

Kishigami S, Mishina Y. 2005. BMP signaling and early embryonic patterning. Cytokine Growth Factor Rev 16: 265-278.

Klein OD, Lyons DB, Balooch G, Marshall GW, Basson MA, Peterka M, Boran T, Peterkova R, Martin GR. 2008. An FGF signaling loop sustains the generation of differentiated progeny from stem cells in mouse incisors. Development 135: 377-385.

Kohn AD, Moon RT. 2005. Wnt and calcium signaling: $\beta$-catenin-independent pathways. Cell Calcium 38: 439-446.

Kowanetz M, Ferrara N. 2006. Vascular endothelial growth factor signaling pathways: Therapeutic perspective. Clin Cancer Res 12: 50185022 .

Kubo F, Nakagawa S. 2009. Hairyl acts as a node downstream of Wnt signaling to maintain retinal stem cell-like progenitor cells in the chick ciliary marginal zone. Development 136: 1823-1833.

Kühl M, Sheldahl LC, Park M, Miller JR, Moon RT. 2000. The Wnt/Ca2 ${ }^{+}$ pathway: A new vertebrate Wnt signaling pathway takes shape. Trends Genet 16: 279-283.

Kurosu H, Ogawa Y, Miyoshi M, Yamamoto M, Nandi A, Rosenblatt KP, Baum MG, Schiavi S, Hu MC, Moe OW, et al. 2006. Regulation of fibroblast growth factor-23 signaling by klotho. J Biol Chem 281: $6120-6123$.

Kurosu H, Choi M, Ogawa Y, Dickson AS, Goetz R, Eliseenkova AV, Mohammadi M, Rosenblatt KP, Kliewer SA, Kuro-o M. 2007. Tissue-specific expression of $\beta$ Klotho and fibroblast growth factor (FGF) receptor isoforms determines metabolic activity of FGF19 and FGF21. J Biol Chem 282: 26687-26695.

Labalette C, Bouchoucha YX, Wassef MA, Gongal PA, Le Men J, Becker T, Gilardi-Hebenstreit P, Charnay P. 2010. Hindbrain patterning requires fine-tuning of early krox 20 transcription by Sprouty 4 . Development 138: $317-326$.

Ladher RK, Wright TJ, Moon AM, Mansour SL, Schoenwolf GC. 2005. FGF8 initiates inner ear induction in chick and mouse. Genes Dev 19: $603-613$

Lanford PJ, Lan Y, Jiang R, Lindsell C, Weinmaster G, Gridley T, Kelley MW. 1999. Notch signalling pathway mediates hair cell development in mammalian cochlea. Nat Genet 21: 289-292.

Lee JS, Yu Q, Shin JT, Sebzda E, Bertozzi C, Chen M, Mericko P, Stadtfeld M, Zhou D, Cheng L, et al. 2006. Klf2 is an essential regulator of vascular hemodynamic forces in vivo. Dev Cell 11: 845-857.

Lemmon MA, Schlessinger J. 2010. Cell signaling by receptor tyrosine kinases. Cell 141: 1117-1134.

LeRoith D, Yakar S. 2007. Mechanisms of disease: Metabolic effects of growth hormone and insulin-like growth factor 1. Nat Clin Pract Endocrinol Metab 3: 302-310.

Lewandoski M, Sun X, Martin GR. 2000. Fgf8 signalling from the AER is essential for normal limb development. Nat Genet 26: 460-463.

Li X. 2005. Sclerostin binds to LRP5/6 and antagonizes canonical Wnt signaling. J Biol Chem 280: 19883-19887.

Li S, Esterberg R, Lachance V, Ren D, Radde-Gallwitz K, Chi F, Parent J-L, Fritz A, Chen P. 2011. Rack1 is required for Vangl2 membrane localization and planar cell polarity signaling while attenuating canonical Wnt activity. Proc Natl Acad Sci 108: 2264-2269.

Lin CR, Chen WS, Lazar CS, Carpenter CD, Gill GN, Evans RM, Rosenfeld MG. 1986. Protein kinase C phosphorylation at Thr 654 of the unoccupied EGF receptor and EGF binding regulate functional receptor loss by independent mechanisms. Cell 44: 839-848.

Lin Y, Zhang J, Zhang Y, Wang F. 2007. Generation of an Frs $2 \alpha$ conditional null allele. Genesis 45: 554-559.

Lin Y, Chen L, Lin C, Luo Y, Tsai RYL, Wang F. 2009. Neuron-derived FGF9 is essential for scaffold formation of Bergmann radial fibers and migration of granule neurons in the cerebellum. Dev Biol 329: 44-54.

Liu Z, Lavine KJ, Hung IH, Ornitz DM. 2007. FGF18 is required for early chondrocyte proliferation, hypertrophy and vascular invasion of the growth plate. Dev Biol 302: 80-91. 
Louvi A, Grove EA. 2011. Cilia in the CNS: The quiet organelle claims center stage. Neuron 69: 1046-1060.

Lovicu FJ, McAvoy JW. 2005. Growth factor regulation of lens development. Dev Biol 280: 1-14.

Lowery JW, de Caestecker MP. 2010. BMP signaling in vascular development and disease. Cytokine Growth Factor Rev 21: 287-298.

Lu W, Yamamoto V, Ortega B, Baltimore D. 2004. Mammalian Ryk is a Wnt coreceptor required for stimulation of neurite outgrowth. Cell 119: $97-108$

Ma Y, Erkner A, Gong R, Yao S, Taipale J, Basler K, Beachy PA. 2002. Hedgehog-mediated patterning of the mammalian embryo requires transporter-like function of dispatched. Cell 111: 63-75.

Mahmood R, Mason I, Morriss-Kay G. 1996. Expression of Fgf-3 in relation to hindbrain segmentation, otic pit position and pharyngeal arch morphology in normal and retinoic acid-exposed mouse embryos. Anat Embryol 194: 13-22.

Maier E, von Hofsten J, Nord H, Fernandes M, Paek H, Hébert JM, Gunhaga L. 2010. Opposing Fgf and Bmp activities regulate the specification of olfactory sensory and respiratory epithelial cell fates. Development 137: 1601-1611.

Mammoto A, Ingber DE. 2009. Cytoskeletal control of growth and cell fate switching. Curr Opin Cell Biol 21: 864-870.

Mammoto T, Ingber DE. 2010. Mechanical control of tissue and organ development. Development 137: 1407-1420.

Mammoto A, Connor KM, Mammoto T, Yung CW, Huh D, Aderman CM, Mostoslavsky G, Smith LEH, Ingber DE. 2009. A mechanosensitive transcriptional mechanism that controls angiogenesis. Nature 457: $1103-1108$.

Mao B, Wu W, Davidson G, Marhold J, Li M, Mechler BM, Delius H, Hoppe D, Stannek P, Walter C, et al. 2002. Kremen proteins are Dickkopf receptors that regulate Wnt/ $\beta$-catenin signalling. Nature 417: 664-667.

Mao Y, Mulvaney J, Zakaria S, Yu T, Morgan KM, Allen S, Basson MA, Francis-West P, Irvine KD. 2011. Characterization of a Dchs1 mutant mouse reveals requirements for Dchs1-Fat4 signaling during mammalian development. Development 138: 947-957.

Marikawa Y. 2006. Wnt/ $\beta$-catenin signaling and body plan formation in mouse embryos. Semin Cell Dev Biol 17: 175-184.

Marshall CJ. 1995. Specificity of receptor tyrosine kinase signaling: Transient versus sustained extracellular signal-regulated kinase activation. Cell 80: 179-185.

Mason JM, Morrison DJ, Basson MA, Licht JD. 2006. Sprouty proteins: Multifaceted negative-feedback regulators of receptor tyrosine kinase signaling. Trends Cell Biol 16: 45-54.

Matsuyama M, Aizawa S, Shimono A. 2009. Sfrp controls apicobasal polarity and oriented cell division in developing gut epithelium. PLoS Genet 5: e1000427.

McCarthy RA, Barth JL, Chintalapudi MR, Knaak C, Argraves WS. 2002. Megalin functions as an endocytic sonic hedgehog receptor. J Biol Chem 277: 25660-25667.

McKay I. 1996. The role of FGF-3 in early inner ear development: An analysis in normal and Kreisler mutant mice. Dev Biol 174: 370-378.

Mii Y, Taira M. 2009. Secreted Frizzled-related proteins enhance the diffusion of Wnt ligands and expand their signalling range. Development 136: 4083-4088.

Mishina Y, Suzuki A, Ueno N, Behringer RR. 1995. Bmpr encodes a type I bone morphogenetic protein receptor that is essential for gastrulation during mouse embryogenesis. Genes Dev 9: 3027-3037.

Miyazono K, Maeda S, Imamura T. 2005. BMP receptor signaling: Transcriptional targets, regulation of signals, and signalling cross-talk. $C y$ tokine Growth Factor Rev 16: 251-263.

Miyazono K, Kamiya Y, Morikawa M. 2010. Bone morphogenetic protein receptors and signal transduction. J Biochem 147: 35-51.

Mohammadi M, Olsen SK, Ibrahimi OA. 2005. Structural basis for fibroblast growth factor receptor activation. Cytokine Growth Factor Rev 16: $107-137$.
Monje P, Marinissen MJ, Gutkind JS. 2003. Phosphorylation of the carboxyl-terminal transactivation domain of c-Fos by extracellular signalregulated kinase mediates the transcriptional activation of AP-1 and cellular transformation induced by platelet-derived growth factor. Mol Cell Biol 23: 7030-7043.

Moon AM, Boulet AM, Capecchi MR. 2000. Normal limb development in conditional mutants of Fgf4. Development 127: 989-996.

Moore KA, Polte T, Huang S, Shi B, Alsberg E, Sunday ME, Ingber DE. 2005. Control of basement membrane remodeling and epithelial branching morphogenesis in embryonic lung by Rho and cytoskeletal tension. Dev Dynam 232: 268-281.

Murakami G, Watabe T, Takaoka K, Miyazono K, Imamura T. 2003. Cooperative inhibition of bone morphogenetic protein signaling by Smurf1 and inhibitory Smads. Mol Biol Cell 14: 2809-2817.

Murdoch JN, Copp AJ. 2010. The relationship between sonic Hedgehog signaling, cilia, and neural tube defects. Birth Defects Res A 88: 633652.

Murone M, Rosenthal A, de Sauvage FJ. 1999. Sonic hedgehog signaling by the patched-smoothened receptor complex. Curr Biol 9: 76-84.

Narimatsu M, Bose R, Pye M, Zhang L, Miller B, Ching P, Sakuma R, Luga V, Roncari L, Attisano L, et al. 2009. Regulation of planar cell polarity by Smurf ubiquitin ligases. Cell 137: 295-307.

Natarajan D, Marcos-Gutierrez C, Pachnis V, de Graaff E. 2002. Requirement of signalling by receptor tyrosine kinase RET for the directed migration of enteric nervous system progenitor cells during mammalian embryogenesis. Development 129: 5151-5160.

Oishi I, Suzuki H, Onishi N, Takada R, Kani S, Ohkawara B, Koshida I, Suzuki K, Yamada G, Schwabe GC, et al. 2003. The receptor tyrosine kinase Ror2 is involved in non-canonical Wnt5a/JNK signalling pathway. Genes Cells 8: 645-654.

Oka C, Nakano T, Wakeham A, de la Pompa JL, Mori C, Sakai T, Okazaki S, Kawaichi M, Shiota K, Mak TW, et al. 1995. Disruption of the mouse RBP-J $\kappa$ gene results in early embryonic death. Development 121: 3291-3301.

Okazaki K, Sagata N. 1995. The Mos/MAP kinase pathway stabilizes cFos by phosphorylation and augments its transforming activity in NIH 3T3 cells. Dev Genes Evol 14: 5048-5059.

Paek H, Gutin G, Hébert JM. 2009. FGF signaling is strictly required to maintain early telencephalic precursor cell survival. Development 136: 2457-2465.

Paek H, Hwang J-Y, Zukin RS, Hébert JM. 2011. $\beta$-Catenin-dependent FGF signaling sustains cell survival in the anterior embryonic head by countering Smad4. Dev Cell 20: 689-699.

Pagès G, Guérin S, Grall D, Bonino F, Smith A, Anjuere F, Auberger P, Pouysségur J. 1999. Defective thymocyte maturation in p44 MAP kinase (Erk 1) knockout mice. Science 286: 1374-1377.

Pajni-Underwood S, Wilson CP, Elder C, Mishina Y, Lewandoski M. 2007. BMP signals control limb bud interdigital programmed cell death by regulating FGF signaling. Development 134: 2359-2368.

Park EJ, Ogden LA, Talbot A, Evans S, Cai C-L, Black BL, Frank DU, Moon AM. 2006. Required, tissue-specific roles for Fgf8 in outflow tract formation and remodeling. Development 133: 2419-2433.

Parkash V, Leppanen VM, Virtanen H, Jurvansuu JM, Bespalov MM, Sidorova YA, Runeberg-Roos P, Saarma M, Goldman A. 2008. The structure of the glial cell line-derived neurotrophic factor-coreceptor complex: Insights into RET signaling and heparin binding. J Biol Chem 283: 35164-35172.

Parker KK, Brock AL, Brangwynne C, Mannix RJ, Wang N, Ostuni E, Geisse NA, Adams JC, Whitesides GM, Ingber DE. 2002. Directional control of lamellipodia extension by constraining cell shape and orienting cell tractional forces. FASEB J 16: 1195-1204.

Pellegrino MJ, Stork PJS. 2006. Sustained activation of extracellular signal-regulated kinase by nerve growth factor regulates c-fos protein stabilization and transactivation in PC12 cells. I Neurochem 99: $1480-1493$. 
Pieroni E, de la Fuente van Bentem S, Mancosu G, Capobianco E, Hirt H, de la Fuente A. 2008. Protein networking: Insights into global functional organization of proteomes. Proteomics 8: 799-816.

Plotnikov AN, Schlessinger J, Hubbard SR, Mohammadi M. 1999. Structural basis for FGF receptor dimerization and activation. Cell 98: 641-650.

Porter JA, Ekker SC, Park WJ, von Kessler DP, Young KE, Chen CH, Ma Y, Woods AS, Cotter RJ, Koonin EV, et al. 1996a. Hedgehog patterning activity: Role of a lipophilic modification mediated by the carboxyterminal autoprocessing domain. Cell 86: $21-34$.

Porter JA, Young KE, Beachy PA. 1996b. Cholesterol modification of hedgehog signaling proteins in animal development. Science 274: 255259.

Pringle N. 1996. Determination of neuroepithelial cell fate: Induction of the oligodendrocyte lineage by ventral midline cells and sonic hedgehog. Dev Biol 177: 30-42.

Qian D, Jones C, Rzadzinska A, Mark S, Zhang X, Steel KP, Dai X, Chen P. 2007. Wnt5a functions in planar cell polarity regulation in mice. Dev Biol 306: 121-133.

Randhawa RS. 2008. The insulin-like growth factor system and fetal growth restrictionn. Pediatr Endocrinol Rev 6: 235-240.

Rattner A, Hsieh JC, Smallwood PM, Gilbert DJ, Copeland NG, Jenkins NA, Nathans J. 1997. A family of secreted proteins contains homology to the cysteine-rich ligand-binding domain of frizzled receptors. Proc Natl Acad Sci 94: 2859-2863.

Ribes V, Briscoe J. 2009. Establishing and interpreting graded Sonic Hedgehog signalling during vertebrate neural tube patterning: The role of negative feedback. Cold Spring Harb Perspect Biol 1: a002014.

Ribes V, Wang Z, Dollé P, Niederreither K. 2006. Retinaldehyde dehydrogenase 2 (RALDH2)-mediated retinoic acid synthesis regulates early mouse embryonic forebrain development by controlling FGF and sonic hedgehog signaling. Development 133: 351-361.

Robertson S, Tynan J, Donoghue D. 2000. RTK mutations and human syndromes: When good receptors turn bad. Trends Genet 16: 368 .

Ron D, Fuchs Y, Chorev D. 2008. Know thy Sef: A novel class of feedback antagonists of receptor tyrosine kinase signaling. Int J Biochem Cell Biol 40: 2040-2052.

Ruiz i Altaba A, Nguyên V, Palma V. 2003. The emergent design of the neural tube: Prepattern, SHH morphogen and GLI code. Curr Opin Genet Dev 13: 513-521.

Saba-El-Leil MK, Vella FDJ, Vernay B, Voisin L, Chen L, Labrecque N, Ang S-L, Meloche S. 2003. An essential function of the mitogen-activated protein kinase Erk2 in mouse trophoblast development. EMBO Rep 4: 964-968.

Saburi S, Hester I, Fischer E, Pontoglio M, Eremina V, Gessler M, Quaggin SE, Harrison R, Mount R, McNeill H. 2008. Loss of Fat4 disrupts PCP signaling and oriented cell division and leads to cystic kidney disease. Nat Genet 40: 1010-1015.

Sai X, Ladher RK. 2008. FGF signaling regulates cytoskeletal remodeling during epithelial morphogenesis. Curr Biol 18: 976-981.

Samad TA, Rebbapragada A, Bell E, Zhang Y, Sidis Y, Jeong S-J, Campagna JA, Perusini S, Fabrizio DA, Schneyer AL, et al. 2005. DRAGON, a bone morphogenetic protein co-receptor. J Biol Chem 280: 1412214129.

Santos SDM, Verveer PJ, Bastiaens PIH. 2007. Growth factor-induced MAPK network topology shapes Erk response determining PC-12 cell fate. Nat Cell Biol 9: 324-330.

Sapkota G, Alarcón C, Spagnoli FM, Brivanlou AH, Massagué J. 2007. Balancing BMP signaling through integrated inputs into the Smad1 linker. Mol Cell 25: 441-454.

Schlessinger J, Plotnikov AN, Ibrahimi OA, Eliseenkova AV, Yeh BK, Yayon A, Linhardt RJ, Mohammadi M. 2000. Crystal structure of a ternary FGF-FGFR-heparin complex reveals a dual role for heparin in FGFR binding and dimerization. Mol Cell 6: 743-750.

Schmelter M, Ateghang B, Helmig S, Wartenberg M, Sauer H. 2006. Embryonic stem cells utilize reactive oxygen species as transducers of mechanical strain-induced cardiovascular differentiation. FASEB J 20: $1182-1184$.

Schmitt AM, Shi J, Wolf AM, Lu CC, King LA, Zou Y. 2006. Wnt-Ryk signalling mediates medial-lateral retinotectal topographic mapping. Nature 439: 31-37.

Schulze A. 2004. The transcriptional response to Raf activation is almost completely dependent on mitogen-activated protein kinase kinase activity and shows a major autocrine component. Mol Biol Cell 15: $3450-3463$.

Semenov M. 2005. SOST is a ligand for LRP5/LRP6 and a Wnt signaling inhibitor. J Biol Chem 280: 26770-26775.

Sheng N, Xie Z, Wang C, Bai G, Zhang K, Zhu Q, Song J, Guillemot F, Chen Y-G, Lin A, et al. 2010. Retinoic acid regulates bone morphogenic protein signal duration by promoting the degradation of phosphorylated Smad1. Proc Natl Acad Sci 107: 18886-18891.

Shim K, Minowada G, Coling DE, Martin GR. 2005. Sprouty2, a mouse deafness gene, regulates cell fate decisions in the auditory sensory epithelium by antagonizing FGF signaling. Dev Cell 8: 553-564.

Singh AB, Harris RC. 2005. Autocrine, paracrine and juxtacrine signaling by EGFR ligands. Cell Signal 17: 1183-1193.

Sivak J, Petersen L, Amaya E. 2005. Fgf signal interpretation is directed by Sprouty and Spred proteins during mesoderm formation. Dev Cell 8: 689-701.

Solecki DJ, Liu X, Tomoda T, Fang Y, Hatten ME. 2001. Activated Notch2 signaling inhibits differentiation of cerebellar granule neuron precursors by maintaining proliferation. Neuron 31: 557-568.

Sorkin A, Goh LK. 2009. Endocytosis and intracellular trafficking of ErbBs. Exp Cell Res 315: 683-696.

Srinivasan R, Zabuawala T, Huang H, Zhang J, Gulati P, Fernandez S, Karlo JC, Landreth GE, Leone G, Ostrowski MC. 2009. Erk1 and Erk2 regulate endothelial cell proliferation and migration during mouse embryonic angiogenesis. PLOS ONE 4: e8283.

Stanger BZ. 2005. Direct regulation of intestinal fate by Notch. Proc Natl Acad Sci 102: 12443-12448.

Stauber DJ, DiGabriele AD, Hendrickson WA. 2000. Structural interactions of fibroblast growth factor receptor with its ligands. Proc Natl Acad Sci 97: 49-54.

Sun X, Meyers EN, Lewandoski M, Martin GR. 1999. Targeted disruption of Fgf8 causes failure of cell migration in the gastrulating mouse embryo. Genes Dev 13: 1834-1846.

Sun X, Mariani FV, Martin GR. 2002. Functions of FGF signalling from the apical ectodermal ridge in limb development. Nature 418: 501508.

Takahashi T, Ueno H, Shibuya M. 1999. VEGF activates protein kinase Cdependent, but Ras-independent Raf-MEK-MAP kinase pathway for DNA synthesis in primary endothelial cells. Oncogene 18: 2221-2230.

Tanegashima K, Zhao H, Dawid IB. 2008. WGEF activates Rho in the Wnt-PCP pathway and controls convergent extension in Xenopus gastrulation. EMBO J 27: 606-617.

Tang N, Marshall WF, McMahon M, Metzger RJ, Martin GR. 2011. Control of mitotic spindle angle by the RAS-regulated ERK1/2 pathway determines lung tube shape. Science 333: 342-345.

Taylor MD, Liu L, Raffel C, Hui C-c, Mainprize TG, Zhang X, Agatep R, Chiappa S, Gao L, Lowrance A, et al. 2002. Mutations in SUFU predispose to medulloblastoma. Nat Genet 31: 306-310.

Tenzen T, Allen BL, Cole F, Kang J-S, Krauss RS, McMahon AP. 2006. The cell surface membrane proteins Cdo and Boc are components and targets of the Hedgehog signaling pathway and feedback network in mice. Dev Cell 10: 647-656.

Terauchi A, Johnson-Venkatesh EM, Toth AB, Javed D, Sutton MA, Umemori H. 2010. Distinct FGFs promote differentiation of excitatory and inhibitory synapses. Nature 465: 783-787.

Thompson DAW. 1917. On growth and form, pp. xv, 793. Cambridge University Press, Cambridge.

Tobin JL, Di Franco M, Eichers E, May-Simera H, Garcia M, Yan J, Quinlan R, Justice MJ, Hennekam RC, Briscoe J, et al. 2008. Inhibition of neural crest migration underlies craniofacial dysmorphology and 
Hirschsprung's disease in Bardet-Biedl syndrome. Proc Natl Acad Sci 105: 6714-6719.

Toyoda R, Assimacopoulos S, Wilcoxon J, Taylor A, Feldman P, SuzukiHirano A, Shimogori T, Grove EA. 2010. FGF8 acts as a classic diffusible morphogen to pattern the neocortex. Development 137: 34393448 .

Turner N, Grose R. 2010. Fibroblast growth factor signalling: From development to cancer. Nat Rev Cancer 10: 116-129.

Ulloa F, Briscoe J. 2007. Morphogens and the control of cell proliferation and patterning in the spinal cord. Cell Cycle 6: 2640-2649.

Ullrich A, Schlessinger J. 1990. Signal transduction by receptors with tyrosine kinase activity. Cell 61: 203-212.

Unterseher F, Hefele JA, Giehl K, De Robertis EM, Wedlich D, Schambony A. 2004. Paraxial protocadherin coordinates cell polarity during convergent extension via Rho A and JNK. EMBO J 23: 3259-3269.

Urness LD, Paxton CN, Wang X, Schoenwolf GC, Mansour SL. 2010. FGF signaling regulates otic placode induction and refinement by controlling both ectodermal target genes and hindbrain Wnt8a. Dev Biol 340: 595-604.

van Amerongen R, Nawijn M, Franca-Koh J, Zevenhoven J, van der Gulden H, Jonkers J, Berns A. 2005. Frat is dispensable for canonical Wnt signaling in mammals. Genes Dev 19: 425-430.

van Amerongen R, Nusse R. 2009. Towards an integrated view of Wnt signaling in development. Development 136: 3205-3214.

Vitelli F, Lania G, Huynh T, Baldini A. 2010. Partial rescue of the Tbx1 mutant heart phenotype by Fgf8: Genetic evidence of impaired tissue response to Fgf8. J Mol Cell Cardiol 49: 836-840.

Wallace VA. 1999. Purkinje-cell-derived Sonic hedgehog regulates granule neuron precursor cell proliferation in the developing mouse cerebellum. Curr Biol 9: 445-448.

Walsh DW, Godson C, Brazil DP, Martin F. 2010. Extracellular BMPantagonist regulation in development and disease: Tied up in knots. Trends Cell Biol 20: 244-256.

Wang Y, Nathans J. 2007. Tissue/planar cell polarity in vertebrates: New insights and new questions. Development 134: 647-658.

Wang B, Sinha T, Jiao K, Serra R, Wang J. 2011. Disruption of PCP signaling causes limb morphogenesis and skeletal defects and may underlie Robinow syndrome and brachydactyly type B. Hum Mol Genet 20: 271-285.

Weber S, Niessen MT, Prox J, Lullmann-Rauch R, Schmitz A, Schwanbeck R, Blobel CP, Jorissen E, de Strooper B, Niessen CM, et al. 2011. The disintegrin/metalloproteinase Adam10 is essential for epidermal integrity and Notch-mediated signaling. Development 138: 495-505.

Wechsler-Reya RJ, Scott MP. 1999. Control of neuronal precursor proliferation in the cerebellum by Sonic Hedgehog. Neuron 22: 103-114.

Weller M, Krautler N, Mantei N, Suter U, Taylor V. 2006. Jagged 1 ablation results in cerebellar granule cell migration defects and depletion of Bergmann glia. Dev Neurosci 28: 70-80.

White AC. 2006. FGF9 and SHH signaling coordinate lung growth and development through regulation of distinct mesenchymal domains. Development 133: 1507-1517.
Williams SE, Beronja S, Pasolli HA, Fuchs E. 2011. Asymmetric cell divisions promote Notch-dependent epidermal differentiation. $\mathrm{Na}$ ture 470: 353-358.

Wittmann DM, Blöchl F, Trümbach D, Wurst W, Prakash N, Theis FJ. 2009. Spatial analysis of expression patterns predicts genetic interactions at the mid-hindbrain boundary. PLoS Comput Biol 5: e1000569.

Wright TJ, Mansour SL. 2003. Fgf3 and Fgf10 are required for mouse otic placode induction. Development 130: 3379-3390.

Wyngaarden LA, Vogeli KM, Ciruna BG, Wells M, Hadjantonakis AK, Hopyan S. 2010. Oriented cell motility and division underlie early limb bud morphogenesis. Development 137: 2551-2558.

Xu Q, Guo L, Moore H, Waclaw RR, Campbell K, Anderson SA. 2010. Sonic Hedgehog signalling confers ventral telencephalic progenitors with distinct cortical interneuron fates. Neuron 65: 328-340.

Yamaguchi TP, Bradley A, McMahon AP, Jones S. 1999. AWnt5a pathway underlies outgrowth of multiple structures in the vertebrate embryo. Development 126: 1211-1223.

Yashiro K, Zhao X, Uehara M, Yamashita K, Nishijima M, Nishino J, Saijoh Y, Sakai Y, Hamada H. 2004. Regulation of retinoic acid distribution is required for proximodistal patterning and outgrowth of the developing mouse limb. Dev Cell 6: 411-422.

Yu PB, Beppu H, Kawai N, Li E, Bloch KD. 2005. Bone morphogenetic protein (BMP) type II receptor deletion reveals BMP ligand-specific gain of signaling in pulmonary artery smooth muscle cells.J Biol Chem 280: $24443-24450$.

Yu T, Yaguchi Y, Echevarria D, Martinez S, Basson MA. 2011. Sprouty genes are essential for cerebellar morphogenesis by preventing excessive FGF signalling in multiple cell types during development. Development 138: 2957-2968.

Zeng X, Tamai K, Doble B, Li S, Huang H, Habas R, Okamura H, Woodgett J, He X. 2005. A dual-kinase mechanism for Wnt co-receptor phosphorylation and activation. Nat Cell Biol 438: 873-877.

Zhang S, Fei T, Zhang L, Zhang R, Chen F, Ning Y, Han Y, Feng X-H, Meng A, Chen Y-G. 2007. Smad7 antagonizes transforming growth factor $\beta$ signaling in the nucleus by interfering with functional Smad-DNA complex formation. Mol Cell Biol 27: 4488-4499.

Zhang W, Hong M, Bae G-U, Kang J-S, Krauss RS. 2010. Boc modifies the holoprosencephaly spectrum of Cdo mutant mice. Dis Model Mech 4: 368-380.

Zhao H, Yang T, Madakashira BP, Thiels CA, Bechtle CA, Garcia CM, Zhang H, Yu K, Ornitz DM, Beebe DC, et al. 2008. Fibroblast growth factor receptor signaling is essential for lens fiber cell differentiation. Dev Biol 318: 276-288.

Zhong J, Kim H-T, Lyu J, Yoshikawa K, Nakafuku M, Lu W. 2011. The Wnt receptor Ryk controls specification of GABAergic neurons versus oligodendrocytes during telencephalon development. Development 138: $409-419$.

Zimmer C, Lee J, Griveau A, Arber S, Pierani A, Garel S, Guillemot F. 2009. Role of Fgf8 signalling in the specification of rostral Cajal-Retzius cells. Development 137: 293-302.

Zwang Y, Yarden Y. 2009. Systems biology of growth factor-induced receptor endocytosis. Traffic 10: 349-363. 


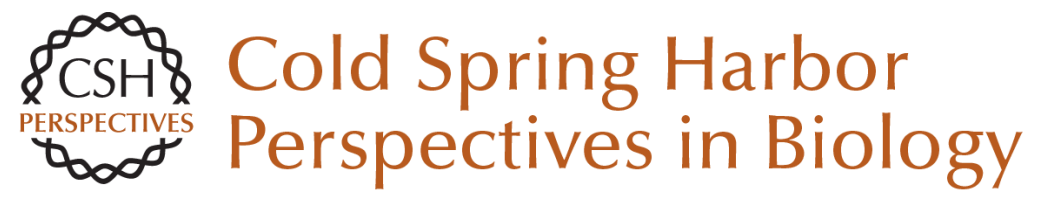

\title{
Signaling in Cell Differentiation and Morphogenesis
}

\author{
M. Albert Basson
}

Cold Spring Harb Perspect Biol 2012; doi: 10.1101/cshperspect.a008151 originally published online May 8, 2012

\section{Subject Collection Mammalian Development}

The Dynamics of Morphogenesis in the Early Mouse Embryo

Jaime A. Rivera-Pérez and Anna-Katerina Hadjantonakis

microRNAs as Developmental Regulators Kathryn N. Ivey and Deepak Srivastava

Development of the Endochondral Skeleton Fanxin Long and David M. Ornitz

\section{Adipogenesis}

Kelesha Sarjeant and Jacqueline M. Stephens

Molecular Mechanisms of Inner Ear Development Doris K. Wu and Matthew W. Kelley

Polarity in Mammalian Epithelial Morphogenesis Julie Roignot, Xiao Peng and Keith Mostov

Eye Development and Retinogenesis Whitney Heavner and Larysa Pevny

Primordial Germ Cells in Mice Mitinori Saitou and Masashi Yamaji
Cell Division Modes and Cleavage Planes of Neural Progenitors during Mammalian Cortical Development

Fumio Matsuzaki and Atsunori Shitamukai

Blood and Lymphatic Vessel Formation Victoria L. Bautch and Kathleen M. Caron

Transcriptional Networks in Liver and Intestinal Development

Karyn L. Sheaffer and Klaus H. Kaestner

Pluripotency in the Embryo and in Culture Jennifer Nichols and Austin Smith

Signaling and Transcriptional Networks in Heart Development and Regeneration Benoit G. Bruneau

Signals and Switches in Mammalian Neural Crest Cell Differentiation

Shachi Bhatt, Raul Diaz and Paul A. Trainor

Hematopoiesis Michael A. Rieger and Timm Schroeder

Intercellular Interactions, Position, and Polarity in Establishing Blastocyst Cell Lineages and

Embryonic Axes Robert O. Stephenson, Janet Rossant and Patrick P.L. Tam

For additional articles in this collection, see http://cshperspectives.cshlp.org/cgi/collection/

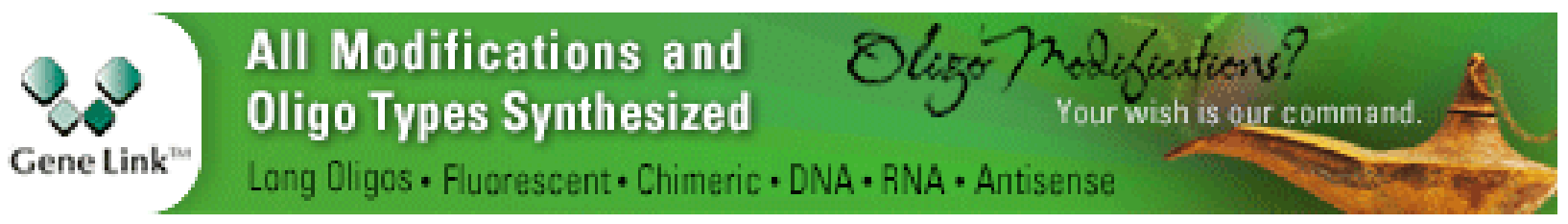

Copyright @ 2012 Cold Spring Harbor Laboratory Press; all rights reserved 